\title{
Principal Component Analysis of Integrated Metal Concentrations of Bogacayi Riverbank Sediments in Turkey
}

\author{
Fusun Yalcin ${ }^{1 *}$, Serpil Kilic ${ }^{2}$, Daniel G. Nyamsari", \\ M. Gurhan Yalcin ${ }^{3}$, Murat Kilic ${ }^{2}$ \\ ${ }^{1}$ Akdeniz University, Department of Mathematics, 07058, Antalya, Turkey \\ ${ }^{2}$ Akdeniz University, Food Safety and Agricultural Research, 07058, Antalya, Turkey \\ ${ }^{3}$ Akdeniz University, Department of Geology, 07058, Antalya, Turkey
}

Received: 16 October 2015

Accepted: 9 December 2015

\begin{abstract}
This research was carried out along the banks of the Bogacayi River in the western part of Antalya in Turkey. We investigated the concentration, average distribution, and level of contamination of the sediments by heavy metals for monitoring purposes. In this study, 25 sediment samples from different stations were collected and analyzed along the Bogacayi's banks. Heavy metals detected in order of abundance are $\mathrm{Mg}>$ $\mathrm{Fe}>\mathrm{Al}>\mathrm{Ti}>\mathrm{MN}>\mathrm{Cr}>\mathrm{Ni}>\mathrm{Ba}>\mathrm{V}>\mathrm{Zr}>\mathrm{Zn}>\mathrm{Co}>\mathrm{Cu}>\mathrm{Pb}>\mathrm{As}>\mathrm{Mo}>\mathrm{W}>\mathrm{Cd}>\mathrm{Sb}>\mathrm{Ag}$. The average concentration of each heavy metal elements was compared to those of the earth crust, sandstone, ultrabasic rock, especially with the acceptable limit for Turkey, in order to determine their anomalies. The concentration of $\mathrm{Cr}$ in sample 24 was 19.85 times and $\mathrm{Ni}$ in sample 25 was 19.29-7.71 times higher than the acceptable limit for Turkey. In samples 24 (1.87 times) and 25 (1.85 times), Co was also higher than the acceptable limit for Turkey. As confirmed by the coefficient correlation analysis, the PCA, anthropogenic activities is thought to have possibly contributed most of the $\mathrm{Sb}, \mathrm{Mo}$, and $\mathrm{Pb}$, and led to an increase in the quantities of elements such as: Fe, V, Mn, Co, Ni, Mg, Cr, and As. Most of the Al, Ti, Zr, Zn, W, Ba, and $\mathrm{Cu}$, and a majority of the $\mathrm{Fe}, \mathrm{V}, \mathrm{Mn}$, and $\mathrm{Sn}$, potentially resulted from a natural source. Samples 24 ( $\mathrm{Zn}$, $\mathrm{Co}, \mathrm{Mn}, \mathrm{Fe}, \mathrm{V}, \mathrm{Cr}, \mathrm{Mg}$, and $\mathrm{Ba}$ ) and 25 (Ni, $\mathrm{Co}, \mathrm{Fe}$, and $\mathrm{Mg}$ ) contain several numbers of heavy metals, each showing high anomalous concentrations, which are related to anthropogenic sources. The ANOVA model summary reveals the high explanatory power of $\mathrm{R}^{2}=100.00 \%$, indicating that the number of samples used in this study was sufficient.
\end{abstract}

Keywords: heavy metals, river sediments, multivariate analysis, principal components analysis

*e-mail: fusunyalcin@akdeniz.edu.tr 


\section{Introduction}

The contamination of soils and sediments by heavy metals are known to be the most serious environmental problem and has significant implications for human health processes $[1,2]$. "Heavy metals" refers to metallic elements with similar chemical properties that are toxic, persistent, non-biodegradable, and poisonous - even at lower concentrations [3-5]. They can either be introduced into the environment naturally (by chemical leaching of bedrocks, water drainage basins, and runoff from banks) and/or from anthropogenic sources (mining operations, disposal of industrial wastes, applications of biocides for pests, automobile exhausts, and combustion by-production from coal-burning power plants [6-10]. Most heavy metals introduced in the environment are usually known to be trapped in sediments by forming stable complexes with sediment organic matter, carbonates, and iron $(\mathrm{Fe})$ - manganese $(\mathrm{Mn})$ oxides $[11,12]$. Human beings can easily be affected by heavy metals through body contact, inhalation of heavy metal-polluted dust, and intake of food $[8,13,14]$. An assessment of the distribution and contamination level of the soil, sediments, and water by these elements is of great importance to disaster risk reduction.

In this light, this study was carried out along the banks of the Bogacayi River in Antalya, which flows from the Mediterranean Sea, in order to determine the heavy metal content of its sediments. The study area which hosts villages close to the river banks will be a great tourist attraction in the near future, considering the mega touristic project that has to be established there. It is necessary and important to investigate the area for its potential of heavy metal threats to the ecosystem by investigating their distribution and sources, to mitigate environmental pollution and reduce exposure risk [9]. To do this, the multivariate statistical analysis which is the most commonly used method to explain the geogenic and anthropogenic source of heavy metal in sediments [15-18], will be used. Factor analysis is often used within this method [19-22].

Therefore, the purpose of this project is to evaluate the concentrations and average distributions of heavy metals by chemical analysis, assess the contamination level, and statistically analyze the heavy metals in Bogacayi riverbank sediments for monitoring purposes.

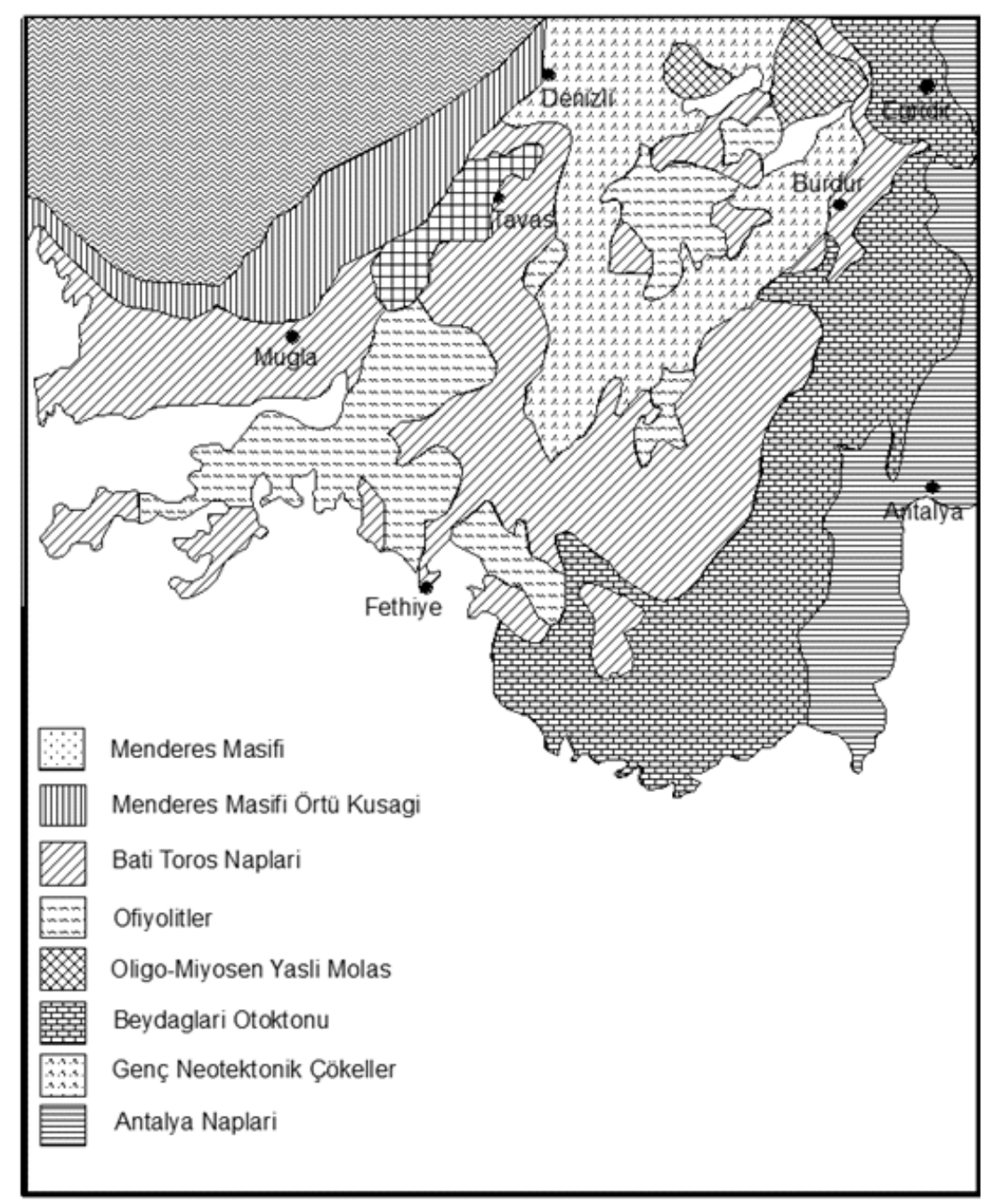

Fig. 1. View of the west Taurus Unit (Ersoy, 1990). 


\section{Geological Setting}

Bogacayi riverbanks are located at the south end of the Taurus orogenic belt of the western Tantains, located near the Kemer and Konyaalti beach break in Korkuteli in the western part of Antalya. This area is covered with sediments.

The geology of the study area ranges from the Mesozoic to the Cenozoic time interval. The allochthonous formation is composed of exposed igneous and sedimentary rocks independent of each other. In this area dolomite, cherty dolomite, and dolomitic limestone represent the upper Triassic-Lower Jurassic, which seems older at the base of the Kayakoy formation, tectonically overlaid the upper Jurassic-lower cretaceous Babadag formation, which is composed of cherts nodules and micritic textured limestone.

Spilitic basaltic rocks overlie the upper cretaceous aged Covenliplateau formation that also overlies the Babadag formation tectonically. Harzburgite, dunite, serpentinite and pyroxene make up the upper cretaceous unit. All these are unconformably covered by dirty yellow, grayish colour conglomerate, clay stone, and sandstone formations forming the Pliocene unit and the quaternary alluvium, talus, and beach sands.

In this region basic and ultrabasic rocks are in contact with dykes along the fault zone and also in the massive peridotite crack and fracture are serpentinized [23].

Generally the study area is represented by the Antalya nappes (Fig. 1). Antalya nappes is divided into three different units: Cataltepe (clay, limestone, sandstone, and radiolarians), Alakircay-Ispartacayi (sandstone, limestone, radiolarians, ophiolitic rocks), and Tahtalidag (carbonates and sedimentary rocks) [24].

\section{Material and Method}

The first field work of this project was carried out in May 2013 around the Bogacayi riverbanks. Samples of $2 \mathrm{~kg}$ each were collected at depths of $10 \mathrm{~cm}$ from 25 different stations located about $500 \mathrm{~m}$ from each other. The samples were prepared at Akdeniz University's geology laboratory and analyzed for their heavical techniques at the ACME Laboratory Ltd., Canada.

The samples were carefully collected, avoiding gravel tracks with the use of a plastic shovel and stored in plastic bags for transportation. The GPS location of each sample was noted in an exercise book using a pen. Based on the U.S. EPA 1992, ASTM 2000 sampling requirements for sediment types, waiting time, and storage conditions, the collected samples were stored inside a freezer in plastic bags with $\mathrm{pH}<2$ adjusted with the use of $\mathrm{HNO}_{3}$, to prepare them for analysis. Before the samples taken to the laboratory were analyzed, they were passed through processes of $\mathrm{pH}$ measurement, drying, grinding, sieving, weighing, and being stored with acid in parts.

Firstly, the $\mathrm{pH}$ value was evaluated. To do these, 20 grams of a sample were put in a $50 \mathrm{ml}$ beaker and pure water was added at a ratio of $1: 2.5$. This was thoroughly shaken, kept for 10 minutes, and the beaker was stirred again, after which the $\mathrm{pH}$ was measured with the use of a $\mathrm{pH}$ meter.

The samples for chemical analysis were kept under normal conditions of room temperature for 24 hours. Using a precision weighing scale, 100 grams of the samples were measured, put on wet paper laid on the ground, labeled, and dried for 24 hours ian oven at $105^{\circ} \mathrm{C}$. After drying, sample weights were measured again using a precision scale.

$100 \mathrm{~g}$ of the dried sample were taken and the amount of each sample remaining was passed through an oscillating mesh sieve and weight distribution of the particle sizes was calculated. Screening was carried out for 10 minutes per sample with sieve sizes of $2,1,0.5,0.25,0.125$, and 0.065 . During the experiment, sieve set, precision scale, brushes, and gloves were dried and washed after every measurement with a $1 \mathrm{~mol} \mathrm{~L}^{-1} \mathrm{HNO}_{3}$ to avoid contamination.

The Geochemical analyses of the samples were determined at the ACME Analytical Laboratories Ltd. Chemical analysis of content made with the Group 1EX (ICP-MS) and 3A01 (ICP-OES) method are given in $\mathrm{mg} /$ $\mathrm{kg}$ and percentage, for a total of 41 elements with reference numbr ANK13001068.

Geochemical data of the elements was then statistically analyzed using SPSS software.

\section{Results}

Data obtained from the Geochemical Analysis of the Bogacayi beach sand samples are presented in Table 1.

In orderabundance in $\mathrm{ppm} \mathrm{mg} / \mathrm{kg}$, the heavy metals occur as follows with minimum, maximum, and mean values, respectively: $\operatorname{Mg}(81,600,49,600)$, Fe $(13,300$, $42,500,28,704)$, Al $(14,100,31,000,24,772)$, Ti $(1,130$, 4,190, 2,957.60), Mn (593, 1,435, 1,044.36), Cr (159, $1,985,404.84)$, Ni (172.9, 578.60, 368.16), Ba $(68,222$, 127.36), V (12, 118, 64.56), Zr (26, 78.9, 51.84), Zn (27, $55,41.40)$, Co (12.8, 37.3, 25.13), Cu (14.5, 31.6, 23.83), $\mathrm{Pb}(3.4,11.4,4.66)$, As $(2,8,3.72)$, Mo $(0.40,0.80,0.58)$, $\mathrm{W}(0.20,0.50,0.39), \mathrm{Cd}(0.10,0.40,0.23), \mathrm{Sb}(0.10,0.40$, $0.21)$, and $\mathrm{Ag}(0.10,0.20,0.112)$ Table 2.

The schematic presentation of the box plot (Fig. 2) reveals that some samples actually contain anomalous high concentrations of some elements, such as: sample 1 has a high anomalous concentration of $\mathrm{Pb}$; sample 4 has a higher concentration of As; sample 5 shows an anomalously high concentration of As, and sample 10 has a higher concentration of Mn; sample 13 has a higher concentration of $\mathrm{Ba}$; sample 15 higher concentrations of $\mathrm{Ba}$ and $\mathrm{Zr}$; sample 16 shows a higher concentration of $\mathrm{Ag}$; sample 18 has a higher concentration of Ag; sample 24 has higher concentrations of $\mathrm{Zn}, \mathrm{Co}, \mathrm{Mn}, \mathrm{Fe}, \mathrm{V}, \mathrm{Cr}, \mathrm{Mg}$, and $\mathrm{Ba}$; and sample 25 has higher concentrations of $\mathrm{Ni}, \mathrm{Co}$, $\mathrm{Fe}$, and $\mathrm{Mg}$. 
Table 1. Results of chemical analysis of samples from Bogacayi riverbanks.

\begin{tabular}{|c|c|c|c|c|c|c|c|c|c|c|c|c|c|}
\hline Samples & 1 & 2 & 3 & 4 & 5 & 6 & 7 & 8 & 9 & 10 & 11 & 12 & 13 \\
\hline $\mathrm{Au}$ & 4.4 & 5.2 & 2.7 & 2.7 & 2.1 & 1.9 & 1.9 & 2.8 & 3.5 & 1.9 & 2.7 & 1.3 & 1.6 \\
\hline Mo & 0.8 & 0.4 & 0.6 & 0.7 & 0.4 & 0.6 & 0.5 & 0.5 & 0.6 & 0.6 & 0.7 & 0.4 & 0.4 \\
\hline $\mathrm{Cu}$ & 14.5 & 22.5 & 23.8 & 22 & 22.8 & 23.5 & 26.2 & 22.4 & 25.6 & 23.3 & 31.6 & 21.5 & 26.9 \\
\hline $\mathrm{Pb}$ & 11.4 & 5.6 & 4.8 & 4.7 & 4.3 & 4.4 & 4.1 & 4.1 & 5 & 4.4 & 4.4 & 3.9 & 5.2 \\
\hline $\mathrm{Zn}$ & 27 & 44 & 44 & 41 & 34 & 44 & 41 & 42 & 40 & 43 & 41 & 43 & 42 \\
\hline $\mathrm{Ag}$ & 0.1 & 0.1 & 0.1 & 0.1 & 0.1 & 0.1 & 0.1 & 0.1 & 0.1 & 0.1 & 0.1 & 0.1 & 0.1 \\
\hline $\mathrm{Ni}$ & 172.9 & 334.1 & 351.1 & 321.6 & 353.4 & 425.4 & 344.3 & 440 & 440.2 & 350.6 & 438.5 & 354 & 375.4 \\
\hline $\mathrm{Co}$ & 12.8 & 22.5 & 23.6 & 23.9 & 21.5 & 25.7 & 23.1 & 26.9 & 25.6 & 24.7 & 28.7 & 24.5 & 26.7 \\
\hline $\mathrm{Mn}$ & 593 & 852 & 903 & 1030 & 885 & 1057 & 983 & 975 & 1006 & 1435 & 1122 & 1195 & 1003 \\
\hline $\mathrm{Fe}$ & 13300 & 25200 & 26200 & 26900 & 23800 & 28500 & 28400 & 27100 & 28800 & 32000 & 31300 & 28100 & 29300 \\
\hline As & 3 & 5 & 4 & 6 & 8 & 5 & 2 & 2 & 4 & 3 & 5 & 4 & 4 \\
\hline $\mathrm{U}$ & 0.7 & 0.7 & 0.8 & 0.7 & 0.8 & 0.7 & 0.8 & 0.9 & 0.8 & 0.7 & 0.8 & 0.7 & 0.8 \\
\hline Th & 3.4 & 2.4 & 2.1 & 1.8 & 1.3 & 2.2 & 2.1 & 2.1 & 2.5 & 2.1 & 2.3 & 1.8 & 2.8 \\
\hline $\mathrm{Sr}$ & 206 & 192 & 191 & 190 & 177 & 201 & 193 & 196 & 203 & 207 & 200 & 208 & 184 \\
\hline $\mathrm{Cd}$ & 0.1 & 0.2 & 0.2 & 0.2 & 0.2 & 0.3 & 0.3 & 0.3 & 0.2 & 0.3 & 0.2 & 0.4 & 0.2 \\
\hline $\mathrm{Sb}$ & 0.2 & 0.2 & 0.2 & 0.1 & 0.2 & 0.2 & 0.1 & 0.1 & 0.2 & 0.2 & 0.2 & 0.4 & 0.2 \\
\hline $\mathrm{Bi}$ & 0.3 & 0.3 & 0.2 & 0.2 & 0.2 & 0.2 & 0.2 & 0.1 & 0.2 & 0.1 & 0.1 & 0.6 & 0.2 \\
\hline $\mathrm{V}$ & 12 & 54 & 58 & 68 & 54 & 57 & 66 & 56 & 56 & 83 & 71 & 71 & 67 \\
\hline $\mathrm{Ca}$ & 199800 & 144200 & 140600 & 148500 & 151900 & 134100 & 129600 & 138500 & 136200 & 156100 & 125800 & 142700 & 101100 \\
\hline $\mathrm{P}$ & 260 & 460 & 450 & 420 & 300 & 440 & 510 & 440 & 490 & 520 & 500 & 500 & 510 \\
\hline $\mathrm{La}$ & 9.1 & 14 & 13.6 & 13.7 & 10 & 15.2 & 17.2 & 15.4 & 17.8 & 16 & 16.7 & 15.5 & 18 \\
\hline $\mathrm{Cr}$ & 159 & 288 & 298 & 531 & 375 & 390 & 301 & 317 & 256 & 402 & 423 & 549 & 328 \\
\hline $\mathrm{Mg}$ & 35800 & 44000 & 42900 & 41800 & 40900 & 52400 & 45900 & 51700 & 54100 & 47000 & 57300 & 47500 & 46400 \\
\hline $\mathrm{Ba}$ & 68 & 127 & 118 & 101 & 95 & 122 & 128 & 117 & 143 & 129 & 130 & 122 & 145 \\
\hline $\mathrm{Ti}$ & 1130 & 2720 & 2670 & 2680 & 1780 & 2740 & 3150 & 2600 & 2760 & 3390 & 3110 & 3250 & 3140 \\
\hline $\mathrm{Al}$ & 0 & 0 & 0 & 0 & 0 & 0 & 0 & 0 & 0 & 0 & 0 & 0 & 0 \\
\hline $\mathrm{Na}$ & 0 & 0 & 0 & 0 & 0 & 0 & 0 & 0 & 0 & 0 & 0 & 0 & 0 \\
\hline $\mathrm{K}$ & 2800 & 4600 & 4600 & 4300 & 3200 & 5200 & 5300 & 4900 & 5700 & 4600 & 5400 & 4900 & 6200 \\
\hline W & 0.2 & 0.3 & 0.4 & 0.4 & 0.3 & 0.4 & 0.4 & 0.4 & 0.4 & 0.4 & 0.5 & 0.4 & 0.4 \\
\hline $\mathrm{Zr}$ & 26 & 45.4 & 47.2 & 43.7 & 27.7 & 52.4 & 53.2 & 51.5 & 61.7 & 55.4 & 54.7 & 51.6 & 62.2 \\
\hline $\mathrm{Ce}$ & 15 & 25 & 25 & 23 & 17 & 28 & 30 & 26 & 31 & 28 & 29 & 27 & 33 \\
\hline $\mathrm{Sn}$ & 0.5 & 0.6 & 0.6 & 0.4 & 0.4 & 0.6 & 0.5 & 0.5 & 0.6 & 0.7 & 0.5 & 0.7 & 0.7 \\
\hline Y & 7.7 & 11 & 10.9 & 11.3 & 9.4 & 11.6 & 12.4 & 11 & 12.1 & 12.4 & 12.2 & 11.8 & 13 \\
\hline $\mathrm{Nb}$ & 4.9 & 9.6 & 9.9 & 9.1 & 5 & 11.9 & 11.7 & 11.5 & 14.2 & 12.9 & 12.3 & 11.9 & 13.1 \\
\hline $\mathrm{Ta}$ & 0.3 & 0.6 & 0.6 & 0.5 & 0.3 & 0.7 & 0.7 & 0.7 & 0.9 & 0.8 & 0.8 & 0.7 & 0.8 \\
\hline $\mathrm{Sc}$ & 5 & 9 & 8 & 9 & 8 & 8 & 8 & 8 & 8 & 10 & 9 & 9 & 8 \\
\hline $\mathrm{Li}$ & 10.2 & 13.8 & 14.7 & 12.3 & 10.9 & 13 & 14.5 & 12.9 & 14.2 & 13 & 14.6 & 12 & 17.6 \\
\hline $\mathrm{Rb}$ & 12.3 & 16.8 & 16.3 & 16 & 13.9 & 16.3 & 17.1 & 15 & 19.2 & 15.9 & 17.2 & 14.6 & 21.1 \\
\hline $\mathrm{Hf}$ & 0.6 & 1.1 & 1.2 & 1.1 & 0.7 & 1.4 & 1.4 & 1.4 & 1.7 & 1.5 & 1.5 & 1.3 & 1.5 \\
\hline In & 0.05 & 0.05 & 0.05 & 0.05 & 0.05 & 0.05 & 0.05 & 0.05 & 0.05 & 0.05 & 0.05 & 0.05 & 0.05 \\
\hline $\mathrm{Te}$ & 2 & 3.1 & 2.4 & 5 & 5.2 & 4.3 & 3.1 & 4.8 & 5.5 & 5.7 & 1.9 & 3.3 & 4 \\
\hline
\end{tabular}


Continued

\begin{tabular}{|c|c|c|c|c|c|c|c|c|c|c|c|c|}
\hline Samples & 14 & 15 & 16 & 17 & 18 & 19 & 20 & 21 & 22 & 23 & 24 & 25 \\
\hline $\mathrm{Au}$ & 2.3 & 2.1 & 2 & 1.6 & 0.8 & 0.8 & 2 & 2.3 & 1.8 & 0.5 & 0.5 & 1.6 \\
\hline Mo & 0.6 & 0.6 & 0.7 & 0.8 & 0.6 & 0.4 & 0.5 & 0.5 & 0.7 & 0.5 & 0.7 & 0.7 \\
\hline $\mathrm{Cu}$ & 23.4 & 23.2 & 25 & 28.7 & 19.1 & 22 & 24 & 20.5 & 26.1 & 20.1 & 27.8 & 29.3 \\
\hline $\mathrm{Pb}$ & 4.2 & 5.3 & 5 & 5.2 & 3.4 & 3.9 & 4 & 3.4 & 4.3 & 3.6 & 4.1 & 3.8 \\
\hline $\mathrm{Zn}$ & 41 & 47 & 43 & 47 & 35 & 37 & 38 & 35 & 45 & 40 & 55 & 46 \\
\hline $\mathrm{Ag}$ & 0.1 & 0.1 & 0.2 & 0.1 & 0.2 & 0.1 & 0.1 & 0.2 & 0.1 & 0.1 & 0.1 & 0.1 \\
\hline $\mathrm{Ni}$ & 403.5 & 181.8 & 380.5 & 318.6 & 370.3 & 402 & 333.7 & 385.4 & 343.2 & 335.3 & 469.5 & 578.6 \\
\hline Co & 25 & 17.1 & 25.3 & 26 & 23.7 & 26.7 & 24.5 & 25.3 & 25.8 & 24.3 & 37.3 & 37 \\
\hline $\mathrm{Mn}$ & 1052 & 997 & 1015 & 1002 & 1056 & 1016 & 1142 & 1103 & 1285 & 1017 & 1350 & 1035 \\
\hline $\mathrm{Fe}$ & 29000 & 26800 & 29000 & 30300 & 26900 & 28100 & 30100 & 28200 & 32300 & 28000 & 42500 & 37500 \\
\hline As & 2 & 2 & 3 & 4 & 3 & 3 & 2 & 3 & 4 & 3 & 5 & 4 \\
\hline $\mathrm{U}$ & 0.8 & 0.9 & 0.9 & 0.8 & 0.8 & 1 & 0.8 & 0.9 & 0.8 & 0.9 & 0.9 & 0.8 \\
\hline $\mathrm{Th}$ & 2.3 & 3.5 & 2.8 & 2.9 & 1.6 & 2.2 & 1.9 & 1.9 & 2.4 & 2.3 & 2 & 2.2 \\
\hline $\mathrm{Sr}$ & 192 & 210 & 189 & 192 & 234 & 201 & 212 & 221 & 205 & 198 & 188 & 168 \\
\hline $\mathrm{Cd}$ & 0.1 & 0.1 & 0.2 & 0.3 & 0.2 & 0.2 & 0.4 & 0.2 & 0.2 & 0.1 & 0.4 & 0.2 \\
\hline $\mathrm{Sb}$ & 0.2 & 0.2 & 0.2 & 0.4 & 0.2 & 0.1 & 0.4 & 0.1 & 0.2 & 0.1 & 0.4 & 0.2 \\
\hline $\mathrm{Bi}$ & 0.2 & 0.2 & 0.2 & 0.6 & 0.1 & 0.1 & 0.6 & 0.2 & 0.1 & 0.1 & 0.5 & 0.2 \\
\hline $\mathrm{V}$ & 67 & 62 & 64 & 71 & 58 & 54 & 69 & 64 & 76 & 59 & 118 & 79 \\
\hline $\mathrm{Ca}$ & 117700 & 154600 & 104500 & 101900 & 155500 & 123400 & 144200 & 146100 & 130900 & 128400 & 122100 & 104500 \\
\hline $\mathrm{P}$ & 480 & 770 & 530 & 560 & 490 & 460 & 470 & 490 & 530 & 480 & 490 & 500 \\
\hline $\mathrm{La}$ & 16 & 23.3 & 16.9 & 18.7 & 15.3 & 15.6 & 15.9 & 15.4 & 17.9 & 16.6 & 15.5 & 16 \\
\hline $\mathrm{Cr}$ & 281 & 174 & 229 & 254 & 242 & 261 & 280 & 315 & 487 & 301 & 1985 & 695 \\
\hline $\mathrm{Mg}$ & 51100 & 27000 & 48500 & 46200 & 50000 & 56100 & 48800 & 53400 & 51300 & 49500 & 68800 & 81600 \\
\hline $\mathrm{Ba}$ & 122 & 165 & 129 & 136 & 123 & 121 & 123 & 124 & 132 & 125 & 222 & 117 \\
\hline $\mathrm{Ti}$ & 2910 & 4050 & 2960 & 3470 & 2880 & 2640 & 3240 & 2800 & 3550 & 2890 & 4190 & 3240 \\
\hline $\mathrm{Al}$ & 0 & 0 & 0 & 0 & 0 & 0 & 0 & 0 & 0 & 0 & 0 & 0 \\
\hline $\mathrm{Na}$ & 0 & 0 & 0 & 0 & 0 & 0 & 0 & 0 & 0 & 0 & 0 & 0 \\
\hline $\mathrm{K}$ & 5400 & 6600 & 6400 & 6500 & 4900 & 5100 & 5200 & 4800 & 5600 & 5200 & 4800 & 5300 \\
\hline W & 0.4 & 0.5 & 0.5 & 0.4 & 0.3 & 0.4 & 0.4 & 0.3 & 0.5 & 0.4 & 0.4 & 0.4 \\
\hline $\mathrm{Zr}$ & 52.9 & 78.9 & 59.2 & 59.2 & 47.4 & 49.3 & 51.5 & 46.9 & 57.5 & 53.5 & 52.7 & 54.4 \\
\hline $\mathrm{Ce}$ & 29 & 40 & 32 & 33 & 27 & 28 & 27 & 27 & 32 & 29 & 27 & 28 \\
\hline Sn & 0.4 & 0.8 & 0.7 & 0.7 & 0.5 & 0.5 & 0.7 & 0.4 & 0.6 & 0.5 & 0.6 & 0.5 \\
\hline $\mathrm{Y}$ & 12 & 15.5 & 13.1 & 13.3 & 11.9 & 11.7 & 12.6 & 11.4 & 13.1 & 13.2 & 12.6 & 11.5 \\
\hline $\mathrm{Nb}$ & 11.3 & 17.9 & 12.1 & 12.6 & 10.4 & 10.6 & 11.3 & 10.1 & 12.8 & 10.7 & 12.6 & 11.6 \\
\hline $\mathrm{Ta}$ & 0.7 & 1.1 & 0.8 & 0.8 & 0.6 & 0.7 & 0.7 & 0.6 & 0.8 & 0.7 & 0.8 & 0.7 \\
\hline $\mathrm{Sc}$ & 8 & 7 & 8 & 9 & 9 & 8 & 11 & 9 & 10 & 9 & 11 & 10 \\
\hline $\mathrm{Li}$ & 14.6 & 16.2 & 17.7 & 17.6 & 13 & 12.9 & 13.8 & 12 & 14.1 & 13.1 & 14.2 & 15.3 \\
\hline $\mathrm{Rb}$ & 17.3 & 23.1 & 21.8 & 22.5 & 14.8 & 17.1 & 15.6 & 14.5 & 17.9 & 15.7 & 14.7 & 17 \\
\hline Hf & 1.2 & 2 & 1.7 & 1.7 & 1.2 & 1.3 & 1.3 & 1.3 & 1.6 & 1.2 & 1.4 & 1.4 \\
\hline In & 0.05 & 0.05 & 0.05 & 0.06 & 0.05 & 0.05 & 0.05 & 0.05 & 0.05 & 0.05 & 0.05 & 0.05 \\
\hline $\mathrm{Te}$ & 3.4 & 3.8 & 1.9 & 3.9 & 4.5 & 3.4 & 2.2 & 2.5 & 1.9 & 2.1 & 3.1 & 2.9 \\
\hline
\end{tabular}


Table 2. Results of heavy metal statistical parameters computed using the chemical data.

\begin{tabular}{|c|c|c|c|c|c|c|c|c|c|c|c|}
\hline & $\mathrm{Au}$ & Mo & $\mathrm{Cu}$ & $\mathrm{Pb}$ & $\mathrm{Zn}$ & $\mathrm{Ag}$ & $\mathrm{Ni}$ & Co & $\mathrm{Mn}$ & $\mathrm{Fe}$ & As \\
\hline Std. Error of Mean & ,2 &, 0 &, 7 &, 3 & 1,1 &, 1 & 16,3 & 1,0 & 32,9 & 997,9 &, 3 \\
\hline Std. Deviation & 1,2 & ,1 & 3,6 & 1,5 & 5,4 &, 4 & 81,4 & 4,8 & 164,6 & 4989,4 & 1,4 \\
\hline Minimum &, 8 &, 4 & 14,5 & 3,4 & 27,0 &, 1 & 172,9 & 12,8 & 593,0 & 13300,0 & 2,0 \\
\hline \multirow[t]{2}{*}{ Maximum } & 5,2 &, 8 & 31,6 & 11,4 & 55,0 & 1,0 & 578,6 & 37,3 & 1435,0 & 42500,0 & 8,0 \\
\hline & Th & $\mathrm{Sr}$ & $\mathrm{Cd}$ & $\mathrm{Sb}$ & $\mathrm{Bi}$ & $\mathrm{V}$ & $\mathrm{Ca}$ & $\mathrm{P}$ & $\mathrm{La}$ & $\mathrm{Cr}$ & $\mathrm{Mg}$ \\
\hline Std. Error of Mean &, 1 & 2,7 &, 0 &, 0 &, 0 & 3,4 & 4318,8 & 17,8 &, 5 & 70,3 & 2044,9 \\
\hline Std. Deviation &, 5 & 13,6 & ,2 &, 1 & ,2 & 17,2 & 21594,2 & 88,9 & 2,7 & 351,3 & 10224,4 \\
\hline Minimum & 1,3 & 168,0 &, 1 &, 1 & ,1 & 12,0 & 101100,0 & 260,0 & 9,1 & 159,0 & 27000,0 \\
\hline \multirow[t]{2}{*}{ Maximum } & 3,5 & 234,0 & 1,0 &, 4 & 6 & 118,0 & 199800,0 & 770,0 & 23,3 & 1985,0 & 81600,0 \\
\hline & $\mathrm{Ba}$ & $\mathrm{Al}$ & $\mathrm{Na}$ & K & $\mathrm{W}$ & $\mathrm{Zr}$ & $\mathrm{Ce}$ & $\mathrm{Sn}$ & $\mathrm{Y}$ & $\mathrm{Nb}$ & $\mathrm{Ta}$ \\
\hline Std. Error of Mean & 5,3 & 695,3 & 136,8 & 176,1 & , 0 & 2,1 & 1,0 &, 0 & ,3 &, 5 &, 0 \\
\hline Std. Deviation & 26,4 & 3476,3 & 683,9 & 880,3 &, 1 & 10,3 & 4,9 &, 1 & 1,4 & 2,6 & ,2 \\
\hline Minimum & 68,0 & 14100,0 & 2520,0 & 2800,0 &, 2 & 26,0 & 15,0 &, 4 & 7,7 & 4,9 &, 3 \\
\hline \multirow[t]{2}{*}{ Maximum } & 222,0 & 31000,0 & 5980,0 & 6600,0 &, 5 & 78,9 & 40,0 &, 8 & 15,5 & 17,9 & 1,1 \\
\hline & $\mathrm{Li}$ & $\mathrm{Rb}$ & $\mathrm{Hf}$ & In & $\mathrm{Te}$ & $\mathrm{U}$ & $\mathrm{Ti}$ & $\mathrm{Sc}$ & & & \\
\hline Std. Error of Mean &, 4 &, 5 &, 1 & ,3 & ,2 &, 0 & 123,5 &, 3 & & & \\
\hline Std. Deviation & 1,9 & 2,7 &, 3 & 1,6 & 1,2 &, 1 & 617,4 & 1,3 & & & \\
\hline Minimum & 10,2 & 12,3 & 6 & , 1 & 1,9 &, 7 & 1130,0 & 5,0 & & & \\
\hline Maximum & 17,7 & 23,1 & 2,0 & 5,0 & 5,7 & 1,0 & 4190,0 & 11,0 & & & \\
\hline
\end{tabular}

\section{Regression}

According to the Model Summary in Table 3, the explanatory power of the data of the chemical elements on $\mathrm{Al}, \mathrm{R}^{2}=100 \%$, indicate a high degree of accuracy of chemical analysis. According to the ANOVA, the 24 descriptive variables (Te, $\mathrm{Au}, \mathrm{Sr}, \mathrm{Sn}, \mathrm{Mo}, \mathrm{Sc}, \mathrm{In}, \mathrm{Ag}, \mathrm{As}$, $\mathrm{Ba}, \mathrm{W}, \mathrm{Cd}, \mathrm{Ni}, \mathrm{U}, \mathrm{Sb}, \mathrm{Cu}, \mathrm{Mn}, \mathrm{P}, \mathrm{Th}, \mathrm{Na}, \mathrm{Bi}, \mathrm{Li}, \mathrm{La}$, and

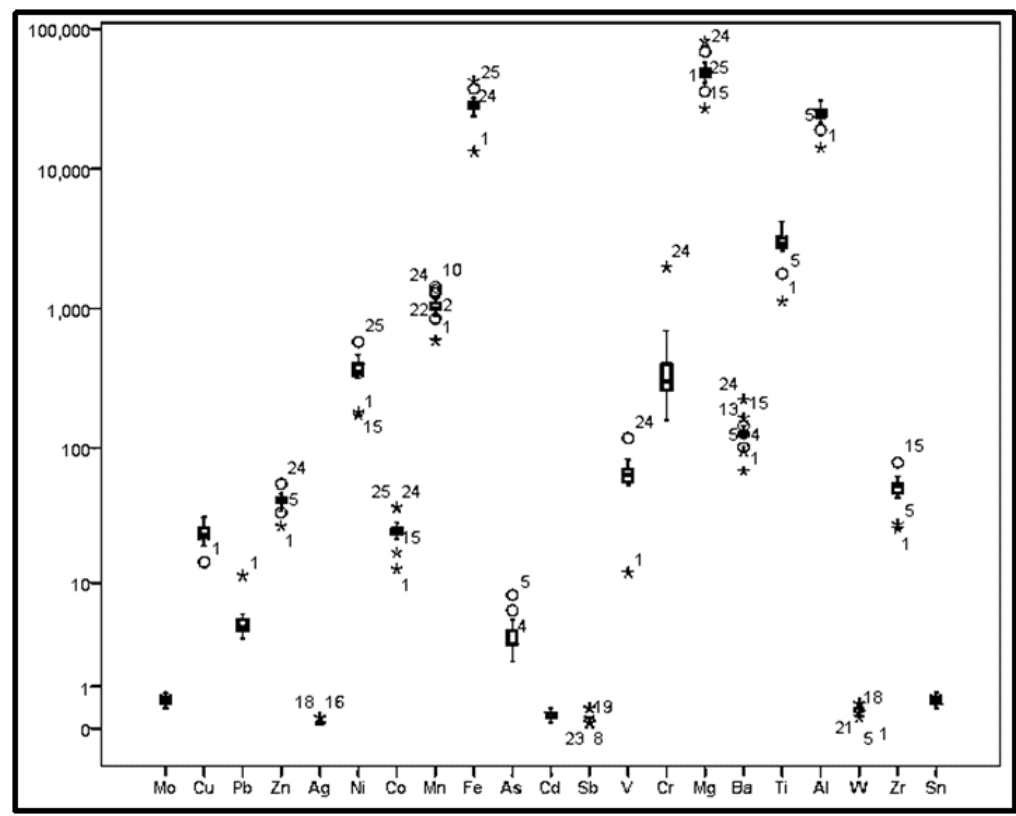

Fig. 2. Concentrations of heavy metals in Bogacayi riverbank sediments. 
Table 3. Data regression of sample content of Bogacayi riverbank sediments using model summary (a) and ANOVA (b).

\begin{tabular}{|c|c|c|c|c|c|c|}
\hline \multicolumn{7}{|c|}{ Model Summary (a) } \\
\hline & Model & $\mathrm{R}$ & R Square & Adjusted R Square & Std. Error of the Estimate & \\
\hline & 1 & $1.000^{\mathrm{a}}$ & 1.000 & & & \\
\hline \multicolumn{7}{|c|}{ ANOVA (b) } \\
\hline & Model & Sum of Squares & df & Mean Square & $\mathrm{F}$ & Sig. \\
\hline \multirow{3}{*}{1} & Regression & 290030400.000 & 24 & 12084600.000 & . &.$^{b}$ \\
\hline & Residual & .000 & 0 & . & & \\
\hline & Total & 290030400.000 & 24 & & & \\
\hline
\end{tabular}

a. Dependent Variable: A1

b. Predictors: (Constant), Te, Au, Sr, Sn, Mo, Sc, In, Ag, As, Ba, W, Cd, Ni, U, Sb, Cu, Mn, P, Th, Na, Bi, Li, La, Mg

$\mathrm{Mg}$ ) on $\mathrm{Al}$ have high explanatory power, suggesting that a sufficient number of samples and heavy metal from the study area were used in the analysis $[17,25,26]$.

\section{Correlation Analysis}

Results of the Pearson correlation coefficient are presented in Table 4. The Pearson correlation coefficient, which is a statistical measurement of the strength of the linear relationships between the variance of the same element (e.g., Al) and another type of element (e.g., Sb) within the samples, indicates a very strong or that a strong positive relationship exists between $\mathrm{Cu}$ and $\mathrm{Zn}, \mathrm{Co}, \mathrm{Fe}, \mathrm{V}$, $\mathrm{Ti}, \mathrm{Al}$, and $\mathrm{W}$; between $\mathrm{Zn}$ and $\mathrm{Co}, \mathrm{Fe}, \mathrm{V}, \mathrm{Ba}, \mathrm{Ti}, \mathrm{Al}, \mathrm{W}$, and $\mathrm{Zr}$; between $\mathrm{Ni}$ and $\mathrm{Co}, \mathrm{Fe}$ and $\mathrm{Mg}$; between $\mathrm{Co}$ and $\mathrm{Fe}$, $\mathrm{V}, \mathrm{Cr}$, and $\mathrm{Mg}$; between $\mathrm{Mn}$ and $\mathrm{Fe}, \mathrm{V}$ and $\mathrm{Ti}$; between $\mathrm{Fe}$ and $\mathrm{V}, \mathrm{Cr}, \mathrm{Mg}, \mathrm{Ba}$, Ti and $\mathrm{Al}$; between $\mathrm{Cd}$ and $\mathrm{Sb}$; between $\mathrm{V}$ and $\mathrm{Cr}, \mathrm{Ba}$, $\mathrm{Ti}$, and $\mathrm{W}$; between $\mathrm{Cr}$ and $\mathrm{Ba}$; between $\mathrm{Ba}$ and $\mathrm{Ti}, \mathrm{Al}$ and $\mathrm{Zr}$; between $\mathrm{Ti}$ and $\mathrm{Al}, \mathrm{W}$, and $\mathrm{Zr}$; between $\mathrm{Al}$ and $\mathrm{W}$ and $\mathrm{Zr}$; between $\mathrm{W}$ and $\mathrm{Zr}$; and between $\mathrm{Zr}$ and $\mathrm{Sn}$. There is a moderate positive relationship between $\mathrm{Cu}$ and $\mathrm{Ni}, \mathrm{Ba}, \mathrm{Zr}, \mathrm{Mn}$ and $\mathrm{Mg}$; between $\mathrm{Zn}$ and $\mathrm{Mn}, \mathrm{Cr}$ and $\mathrm{Sn}$; between $\mathrm{Ni}$ and $\mathrm{V}$ and $\mathrm{Cr}$; between $\mathrm{Co}$ and $\mathrm{Mn}, \mathrm{Ba}$, $\mathrm{Ti}, \mathrm{Cd}$ and $\mathrm{Al}$; between $\mathrm{Mn}$ and $\mathrm{Cu}, \mathrm{Mg}, \mathrm{Al}, \mathrm{Cd}, \mathrm{Cr}, \mathrm{Ba}$, $\mathrm{W}$ and $\mathrm{Zr}$; between $\mathrm{Fe}$ and $\mathrm{Cd}, \mathrm{W}$ and $\mathrm{Zr}$; between $\mathrm{Cd}$ and $\mathrm{Cr}$ and $\mathrm{V}$; between $\mathrm{Sb}$ and $\mathrm{V}, \mathrm{Cr}$ and $\mathrm{Sn}$; between $\mathrm{V}$ and $\mathrm{Mg}, \mathrm{Al}$ and $\mathrm{Zr}$; between $\mathrm{Cr}$ and $\mathrm{Mg}$ and $\mathrm{Ti}$; between $\mathrm{Ba}$ and $\mathrm{W}$ and $\mathrm{Sn}$; between Ti and $\mathrm{Sn}$; between $\mathrm{Al}$ and $\mathrm{Sn}$; and between $\mathrm{W}$ and $\mathrm{Sn}$.

A strong negative relationship exists between $\mathrm{Pb}$ and $\mathrm{Mn}$, and $\mathrm{Fe}$ and $\mathrm{V}$. A moderate negative relationship exists between $\mathrm{Pb}$ and $\mathrm{Ni}, \mathrm{Co}, \mathrm{Ti}, \mathrm{Mg}, \mathrm{Al}$ and $\mathrm{W}$; and between As and $\mathrm{Zr}$.

\section{Cluster Analysis}

Cluster analysis between groups carried out to examine the similarity or homogeneity of the sample reveals six principal cluster groups as shown in Fig. 3. The clusters include samples as follows: Cluster 1 (S 13, 17, and 16), cluster 2 (S 24 and 25), cluster 3 (S 12, 20, 21, 2, 3, 4, 10,
18, and 5), cluster 4 (S 11, 19, 14, 6, 9, 8, 7, 23, and 22), cluster 5 (S 15), and cluster 6 (S 1).

Between the groups, cluster analysis also was carried out on the elements to evaluate the closeness in their relationship to each other as shown in Fig. 4. From the dendrogram, the elements are divided into three cluster groups, cluster 1 ( $\mathrm{Ti}-\mathrm{Ag})$, cluster $2(\mathrm{Fe}, \mathrm{Al}$, and $\mathrm{Mg}-$ which are the most abundant common elements in the earth's crust) [27], and er $3(\mathrm{Ca})$. This Theclusters are is thought to indicate a similar source of the elements.

\section{Factor Anaysis}

The results of the principal component analysis (PCA) of the elements as shown in Tables 5 and 6 indicates that the six components retained have a good representation of all the elements. The six components provide $83.949 \%$ of the

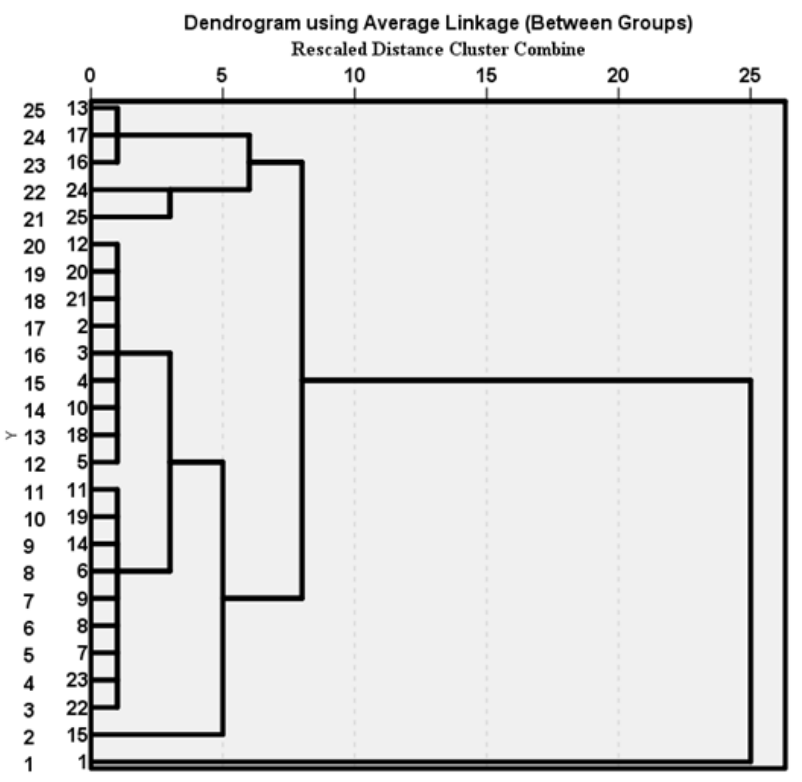

Fig. 3. Hierarchical cluster analysis dendrogram of Bogacayi riverbank samples. 
7

$\bar{n}$

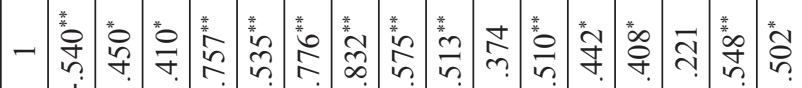

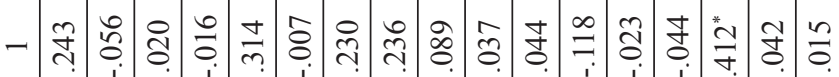

พิ

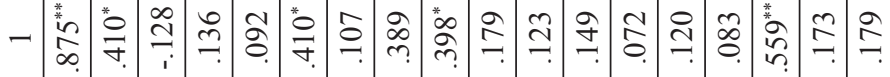

च

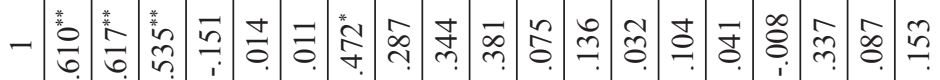
के $-\widehat{\hat{\sigma}}$.

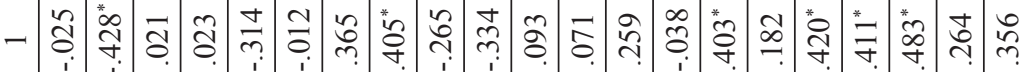

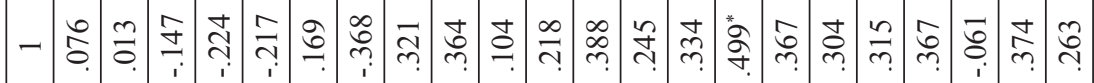

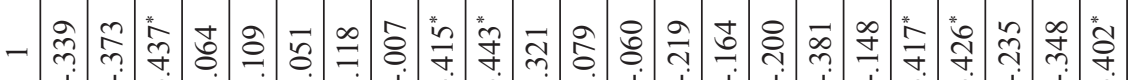

i

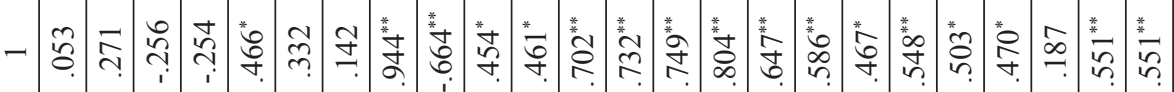

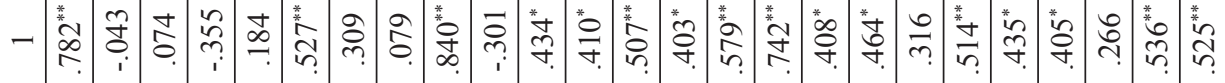

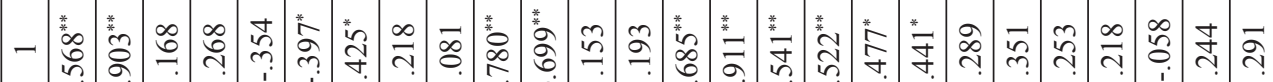

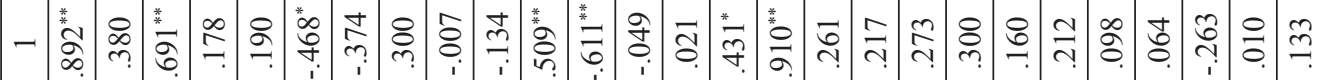




\begin{tabular}{|c|c|c|c|c|c|c|c|c|c|c|c|c|c|c|c|c|c|c|c|c|c|c|c|c|c|c|c|c|c|c|c|c|}
\hline \multirow{2}{*}{\multicolumn{2}{|c|}{ 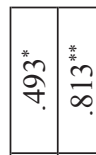 }} & \multirow[b]{2}{*}{ 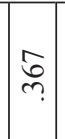 } & \multirow{2}{*}{\multicolumn{2}{|c|}{ 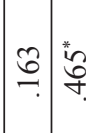 }} & \multirow[b]{2}{*}{\begin{tabular}{lll}
0 & $\infty$ \\
\hdashline & 0 \\
\end{tabular}} & \multirow{2}{*}{ 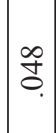 } & & & & & & & & & & & & & & & & & & & & & & & & - & \\
\hline & & & & & & & $\Xi$ & & & & & & & & & & & & & & & & & & & & & & & & $\bar{\infty}$ & \\
\hline 8 & $|\vec{\infty}|$ & ठे & छे & 8 & $\begin{array}{l}* \\
0 \\
0\end{array}$ & \pm & 出 & & & & & & & & & & & & & & & & & & & & & & & & 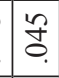 & \\
\hline & & & & & & & حิ & & & & & & & & & & & & & & & & & & & & & & -1 & 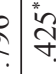 & $\tilde{\widetilde{\sigma}}$ & \\
\hline$\infty$ & $\mid \begin{array}{l}\infty \\
0 \\
o \\
q\end{array}$ & $\mid \frac{\hat{\imath}}{\mathrm{N}}$ & 文 & $\stackrel{f}{\exists}$ & $\vec{\partial}$ & $\stackrel{0}{7}$ & ב & & & & & & & & & & & & & & & & & & & & & & $\begin{array}{c}6 \\
6 \\
6\end{array}$ & & $\stackrel{\infty}{+}$ & \\
\hline$\stackrel{\overbrace{}}{\dddot{\imath}}$ & $\mid$ & 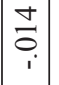 & $\frac{2}{2}$ & $\vec{n}$ & $\mid \begin{array}{c}\infty \\
\stackrel{0}{-1} \\
-1\end{array}$ & $\stackrel{\text { g }}{-}$ & $\ddot{n}$ & & & & & & & & & & & & & & & & & & & & & 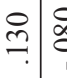 & $\begin{array}{l}0 \\
0 \\
0 \\
\end{array}$ & ?ִ. & 莳 & \\
\hline$\stackrel{\infty}{\circ}$ & $\frac{n}{0}$ & $\vec{m}$ & $\begin{array}{c}\infty \\
\infty \\
\stackrel{0}{-}\end{array}$ & $\begin{array}{l}\infty \\
\infty \\
0\end{array}$ & \&. & $\overrightarrow{\widehat{c}}$ & 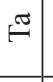 & & & & & & & & & & & & & & & & & & & & & & 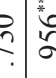 & $\begin{array}{l}0 \\
0\end{array}$ & $\frac{n}{0}$ & \\
\hline & & & & & & & z & & & & & & & & & & & & & & & & & & - & 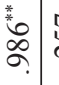 & & : & $3)^{\frac{*}{8}}$ & $\widehat{b}$ & $\stackrel{\square}{ \pm}$ & \\
\hline fo & ֶָ. & f. & in & $\begin{array}{c}\infty \\
? \\
?\end{array}$ & in & $\stackrel{0}{i}$ & $\nu$ & & & & & & & & & & & & & & & & & & ڤั. & 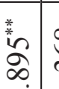 & & & & & fo & \\
\hline$\stackrel{q}{q}$ & ठิે & $\begin{array}{l}8 \\
\stackrel{0}{0} \\
\end{array}$ & 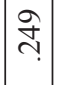 & $\begin{array}{l}\hat{\imath} \\
\tilde{\eta}\end{array}$ & 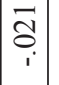 & ָָ & कี & & & & & & & & & & & & & & & & & 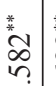 & 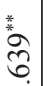 & 蕃 & & 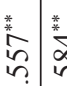 & 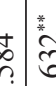 & & ô & \\
\hline 임 & $\stackrel{\widehat{I}}{-}$ & $\overrightarrow{\widetilde{\jmath}}$ & $\mid \begin{array}{c}\infty \\
\cdots \\
i\end{array}$ & \begin{tabular}{c}
$\infty$ \\
\multirow{1}{*}{} \\
$?$ \\
$i$
\end{tabular} & $\vec{O}$ & in & U & & & & & & & & & & & & & & & -1 & 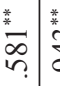 & & ⿳亠丷厂 & F. & 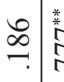 & $\stackrel{*}{*}$ & $\begin{array}{ll}6 \\
6 \\
6\end{array}$ & $\frac{\infty}{\sim}$ & $F_{i}$ & \\
\hline in & $\stackrel{*}{*}$ & 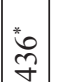 & $\frac{0}{\pi}$ & in & $\hat{8}$ & छे & $\mathbf{N}$ & & & & & & & & & & & & & & - & $\begin{array}{l}0 \\
0 \\
\vdots \\
\vdots \\
0\end{array}$ & & & $\begin{array}{l}\infty \\
\infty \\
\sigma\end{array}$ & $\begin{array}{l}0 \\
\vdots \\
\vdots \\
\vdots\end{array}$ & & & & & స్ర & \\
\hline & & & & & & & 3 & & & & & & & & & & & & & - & \begin{tabular}{l}
\multirow{2}{*}{} \\
$\vdots$
\end{tabular} & 垈 & $\hat{\tilde{f}}$ & 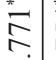 & 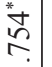 & $\stackrel{\infty}{\infty}$ & તેฺे & 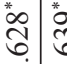 & $b^{6}$ & 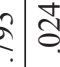 & $\underset{7}{9}$ & d \\
\hline$\vec{n}$ & 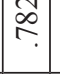 & $\stackrel{?}{-}$ & to & f. & $\tilde{o}_{1}^{0}$ & $\exists$ & $\forall$ & & & & & & & & & & & & & $\left|\begin{array}{l}* \\
\vdots \\
\vdots \\
\vdots \\
\vdots\end{array}\right|$ & $\stackrel{*}{*} \underset{\Sigma}{\sim}$ & 美 & & $\begin{array}{l}* \\
i \\
\infty\end{array}$ & $\begin{array}{l}* \\
0 \\
0\end{array}$ & 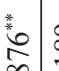 & & & & & $\hat{\delta}$ & $\frac{d}{i}$ \\
\hline ?ి & 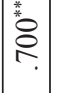 & $\frac{m}{m}$ & $\mid \begin{array}{l}\infty \\
\tilde{\wp}\end{array}$ & 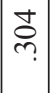 & $\mid$ & $\begin{array}{c}\tilde{b} \\
\vdots \\
i\end{array}$ & $\tilde{z}$ & & & & & & & & & & & - & $\left|\begin{array}{c}* \\
\multirow{2}{*}{} \\
0 \\
0 .\end{array}\right|$ & 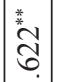 & $\left.\mid \begin{array}{l}* \\
0 \\
0 \\
0 \\
0 \\
0\end{array}\right]$ & $\mid$ & के & $\frac{*}{\infty}$ & 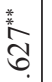 & 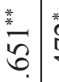 & & & $\begin{array}{c}6 \\
\vdots \\
6\end{array}$ & & $\vec{I}$ & $\nsubseteq$ \\
\hline$\stackrel{\text { I }}{ \pm}$ & $\left|\begin{array}{l}* \\
\vdots \\
\sigma \\
\sigma\end{array}\right|$ & \begin{tabular}{l}
$\tilde{n}$ \\
\hdashline
\end{tabular} & $\left|\begin{array}{l}\infty \\
0 \\
0 \\
i\end{array}\right|$ & $\begin{array}{l}2 \\
7\end{array}$ & $\underset{\cong}{\stackrel{\Xi}{i}}$ & ঠे & « & & & & & & & & & & - & $\mid \begin{array}{l}n \\
6 \\
\infty \\
\infty \\
0\end{array}$ & 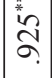 & : & $\vec{\infty}$ & $\mid$ & t: & 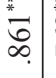 & ?. & $\stackrel{*}{*}$ & 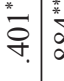 & & & & $\hat{\sigma}_{i}$ & \\
\hline 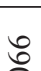 & $\infty$ & 8 & $\simeq$ & 8 & 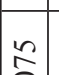 & $\stackrel{\infty}{+}$ & $F$ & & & & & & & & & - & 范 & $\mid \begin{array}{c}* \\
- \\
\infty \\
0 \\
0\end{array}$ & $\stackrel{*}{\gtrless}$ & $\mid \begin{array}{c}* \\
\hat{\infty} \\
0 \\
0\end{array}$ & \begin{tabular}{l}
$*$ \\
\multirow{2}{*}{} \\
$\infty$ \\
$\infty$ \\
0.
\end{tabular} & 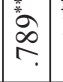 & \begin{tabular}{l}
4 \\
\hdashline \\
$n$
\end{tabular} & 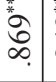 & 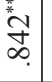 & 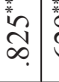 & 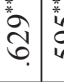 & & 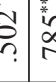 & 6 & $\underbrace{g}_{i}$ & 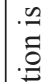 \\
\hline & & & & & & & $\tilde{\oplus}$ & & & & & & & & - & $\begin{array}{l}* \\
0 \\
\infty \\
\infty \\
\infty\end{array}$ & $\begin{array}{c}* \\
\frac{*}{2} \\
0\end{array}$ & 辛 & $\mid \begin{array}{l}* \\
m \\
n \\
n\end{array}$ & $\mid \begin{array}{l}* \\
\\
f\end{array}$ & $\begin{array}{l}* \\
i \\
6 \\
6\end{array}$ & 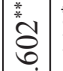 & 总 & $\underset{*}{*}$ & \% & 酋 & 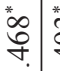 & مُ & $=$ & 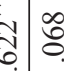 & $\frac{m}{0}$ & $\bar{E}$ \\
\hline 冓 & 伝 & 袉 & 年 & 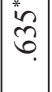 & $\left|\frac{\infty}{\sim}\right|$ & ฮิ & $\sum^{\infty}$ & & & & & & & - & సิ & 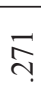 & $\mid \begin{array}{l}\tilde{n} \\
\text { }\end{array}$ & ڤે̣̂ & $\stackrel{2}{0}$ & $\mid \begin{array}{l}\infty \\
-7\end{array}$ & $\begin{array}{l}\infty \\
\vdots \\
0\end{array}$ & $\hat{\tilde{\rho}}$ & ते & ६̊ & छे. & $\stackrel{\overbrace{}}{?}$ & ". & $\stackrel{\overbrace{}}{\varrho}$ & $\begin{array}{l}0 \\
0 \\
i\end{array}$ &. \pm & $\stackrel{m}{?}$ & $\dot{\bar{\theta}}$ \\
\hline$\stackrel{?}{m}$ & $\mid$ & $\left|\begin{array}{c}0 \\
\stackrel{0}{0} \\
i\end{array}\right|$ & $\mid \begin{array}{c}\tilde{N} \\
0 \\
i\end{array}$ & $\begin{array}{l}n \\
\tilde{n} \\
\eta \\
1\end{array}$ & $\begin{array}{l}\text { a } \\
\text { a }\end{array}$ & $\stackrel{5}{0}$ & Ü & & & & & & - & 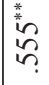 & 悉 & in & $\stackrel{\Xi}{=}$ & 守 & $\left|\begin{array}{l}\infty \\
0 \\
i \\
i\end{array}\right|$ & हे & $\overline{8}$ & $\mid$ & $\begin{array}{l}\infty \\
\stackrel{0}{0} \\
i\end{array}$ & $\begin{array}{l}\infty \\
0 \\
0\end{array}$ & $\hat{o}$ & $\begin{array}{l}\infty \\
\text { oे }\end{array}$ & 殍 & $\stackrel{m}{a}_{i}^{a}$ & 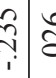 & 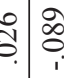 & $\hat{\tilde{c}}$ & $\frac{d}{d}$ \\
\hline in & 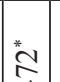 & in & 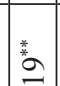 & के & $\begin{array}{l} \pm \\
\infty\end{array}$ & $\hat{n}$ & $\stackrel{\widetilde{\jmath}}{ }$ & & & & & - & है & छे. & 童 & 悉 & 离 & $\underset{*}{\stackrel{*}{\mathbb{N}}}$ & ڤั. & 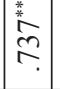 & $\begin{array}{l}0 \\
0 \\
\vdots \\
\vdots\end{array}$ & 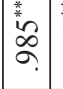 & 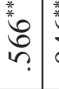 & $\begin{array}{l}* \\
0 \\
0 \\
0\end{array}$ & 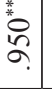 & 莩 & $\vec{\overbrace{}}$ & & & ¿. & $\tilde{\delta}_{i}$ & \\
\hline & & & & & & & a & & & & - & $\begin{array}{l}\text { 委 } \\
\text { nू }\end{array}$ & $\begin{array}{l}0 \\
\text { Q } \\
i\end{array}$ & 悉 & $\frac{7}{6}$ & 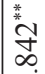 & 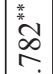 & $\mid$\begin{tabular}{l}
$*$ \\
\multirow{2}{*}{} \\
0 \\
0 \\
0
\end{tabular} & $\mid$ & $\mid$ & $\frac{*}{i}$ & ڤે & 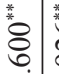 & హ. & $\frac{{ }_{0}^{*}}{\sigma}$ & 蓄 & $\overrightarrow{\widetilde{c}}$ & $\begin{array}{c}5 \\
6 \\
6\end{array}$ & 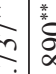 & $D_{0}^{\infty}$ & 文 & \\
\hline oे & $\overrightarrow{\widehat{s}}$ & $\mid \overrightarrow{\vec{े}}$ & $\underline{\Xi}$ & $\left|\begin{array}{c}0 \\
- \\
-\end{array}\right|$ & $\left|\begin{array}{c}\mathbb{1} \\
\text { ? }\end{array}\right|$ & $\frac{5}{9}$ & తూ & & & - & $\begin{array}{c}\infty \\
\text { के }\end{array}$ & & ְై & {$\left[\begin{array}{c}* \\
m \\
n \\
n\end{array}\right.$} & $\begin{array}{l}n \\
\tilde{z} \\
q\end{array}$ & 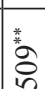 & $\frac{*}{\widetilde{N}}$ & {$\left[\begin{array}{l}* \\
i \\
n \\
n\end{array}\right.$} & $\frac{*}{2}$ & $\left|\begin{array}{l}* \\
\vdots \\
\vdots \\
n\end{array}\right|$ & $\frac{*}{\pi}$ & $\stackrel{*}{*}$ & $\stackrel{n}{n}$ & $\begin{array}{l}* \\
\infty \\
0 \\
0\end{array}$ & 茓 & 密 & $\stackrel{n}{m}$ & 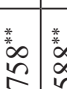 & $\begin{array}{l}\infty \\
\infty \\
0 \\
n\end{array}$ & 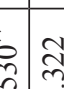 & $\stackrel{\Xi}{\beth}$ & $\frac{b}{n}$ \\
\hline & & & 0 & & & & & & & & & & & & & & & & & & & & & & & & & & & & & \\
\hline ते & F & & $0_{i}^{\infty}$ & $\stackrel{1}{1}$ & $\mid \begin{array}{l}0 \\
0 \\
1\end{array}$ & 8 & $>$ & & & 年 & \begin{tabular}{l|l}
0 \\
$\vdots$ \\
\hdashline \\
\hdashline
\end{tabular} & $\stackrel{*}{*}$ & $\begin{array}{l}x \\
\vdots \\
n \\
n\end{array}$ & {$\left[\begin{array}{l}* \\
i \\
n \\
n \\
n\end{array}\right.$} & 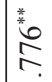 & 密 & 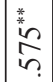 & $\mid \begin{array}{c}* \\
\frac{m}{n} \\
n\end{array}$ & 索 & 蒹 & $\stackrel{*}{\stackrel{*}{f}}$ & $\mid \begin{array}{l}0 \\
0 \\
o \\
q\end{array}$ & $\overrightarrow{\widetilde{N}}$ & $\begin{array}{l}0 \\
0 \\
0 \\
n \\
n\end{array}$ & 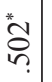 & & \begin{tabular}{l|l}
$*$ \\
$m$ \\
$\infty$
\end{tabular} & \begin{tabular}{lll}
$\hat{0}$ & \multicolumn{2}{c}{}
\end{tabular} & 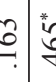 & \begin{tabular}{lll}
$\hat{b}$ & $\infty$ & $\infty$ \\
\hdashline
\end{tabular} & 我 & 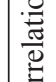 \\
\hline & $\ddot{\varkappa}$ & $\exists$ & $\vec{\approx}$ & 4 & $\Xi$ & 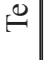 & & & & 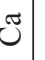 & $a$ & త & U & $\sum^{\infty}$ & ๓็ & 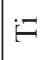 & « & $\tilde{z}$ & $\checkmark$ & 3 & $\vec{N}$ & $\ddot{0}$ & हี & $\lambda$ & $\hat{z}$ & $\pi$ & $\ddot{n}$ & $\exists$ & वे & $\pm \equiv$ & $\ominus$ & \\
\hline
\end{tabular}




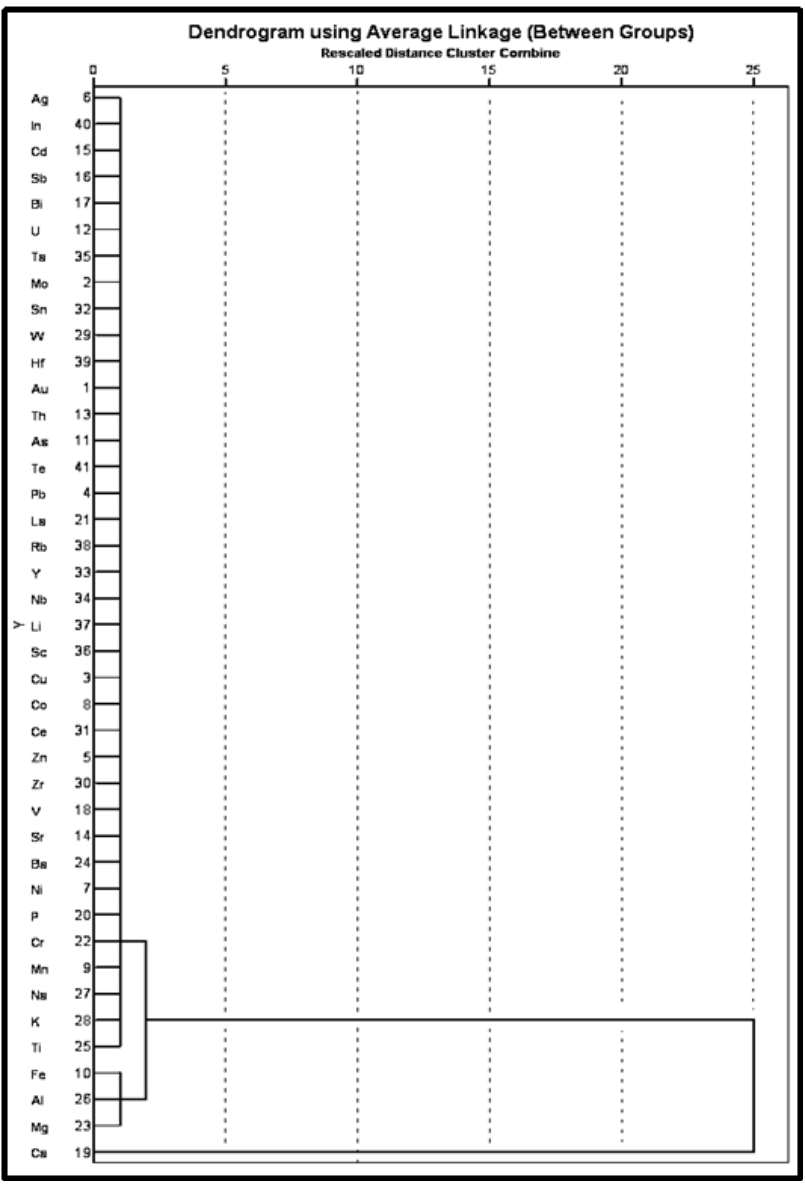

Fig. 4. Elements dendrogram of Bogacayi riverbank sediments.

variables' variance of 41 elements with lowest eigenvalue $>1.5$. Ti (0.927), Al (0.919), Zr (0.901), Zn (0.799), W (0.799), Fe (0.788), Ba (0.777), V (0.736), Cu (0.722), and $\mathrm{Mn}(0.632)$ show their strongest positive correlational relationship in the first component (Factor 1), and the component explains $42.404 \%$ of the total variance with eigenvalue of 17.386. The second component (Factor 2) has the highest indicator values for $\mathrm{Co}(0.730), \mathrm{Ni}(0.697)$, $\mathrm{Mg}$ (0.710), Cr (0.722), Cd (0.546), and As (0.470), and explains $16.906 \%$ of the variance with eigenvalue of 6.931 . The third component (Factor 3 ) has the strongest indicator

Table 5. Explanation of total variance on elements in Bogacayi riverbank sediments.

\begin{tabular}{|c|c|c|c|}
\hline \multirow{2}{*}{ Component } & \multicolumn{3}{|c|}{ Initial Eigenvalues } \\
\cline { 2 - 4 } & Total & \% of Variance & Cumulative \% \\
\hline 1 & 17.386 & 42.404 & 42.404 \\
\hline 2 & 6.931 & 16.906 & 59.310 \\
\hline 3 & 3.510 & 8.561 & 67.872 \\
\hline 4 & 2.988 & 7.289 & 75.160 \\
\hline 5 & 1.866 & 4.551 & 79.711 \\
\hline 6 & 1.738 & 4.238 & 83.949 \\
\hline
\end{tabular}

values for $\mathrm{Sb}(0.782)$ and $\mathrm{Pb}(0.499)$, and explains $8.561 \%$ of the variance with eigenvalue of 3.510 . Component 4 explains $7.289 \%$ of the variance with eigenvalue of 2.988 and $\mathrm{Te}, \mathrm{Sr}$ and $\mathrm{Ca}$ (non heavy metal elements) show their highest values in this component. Component 5 explains $4.551 \%$ of the variance with an eigenvalue of 1.866 , and $\mathrm{Ag}(0.545)$ has it highest indicator value in this component. While component 6 explains $4.238 \%$ of the variance with an eigenvalue of 1.738 , and Mo (0.527) has its highest indicator value in this component. A visual representation of this can be seen on the scree plot in Fig. 5 .

Cluster analysis (CA) is the most suitable method for determining correlation between the variables [28]. Although CA is not significantly different from PCA, PCA is an alternative method used for justification of the results $[15,17]$.

The mean values of the heavy metal concentration were compared to those of the earth crust [29], sandstone [30], ultrabasic rocks [30] and acceptable limit for Turkey [31] values to evaluate the quantitative level in the beach sand as shown in Table 7.

When compared to the average concentration in the earth crust, average concentration for M (591.52 times), Mn (1.04 times), Cr (4.05 times), Ni (4.91 times), Co (1.26 times), Cd (1.52 times), As (2.07 times), Ag (1.6 times), and $\mathrm{Sb}$ (1.04 times) were greater. Compared to the sandstone average concentration, $\mathrm{Fe}$ (2.93 times), $\mathrm{Mg}$ (7.09 times), Ti (1.97 times), Mn (11.6 times), Cr (11.57 times), $\mathrm{Cu}$ (2.65 times), Ni (184.08 times), Co (83.76 times), $\mathrm{Zn}$ (2.59 times), Cd (2.53 times), As (3.72 times), Ag (1.24 times), Mo (2.9 times), Sb (2.31 times), and V (3.23 times) had higher average concentrations. Average concentrations of $\mathrm{Al}$ (1.24 times), Ti (9.86 times), $\mathrm{Cu}$ (2.38 times), $\mathrm{Pb}$ (4.66 times), As (3.72 times), Ag (1.87 times), Mo (1.93 times), Sb (2.08 times), Sn (1.14 times), and V (1.61 times) were greater than thoseltrabasic. and wWhen compared to the acceptable limit for Turkey, $\mathrm{Cr}$ (4.05 times), o (1.26 times), and Ni (12.27-4.91 times) had greater concentrations.

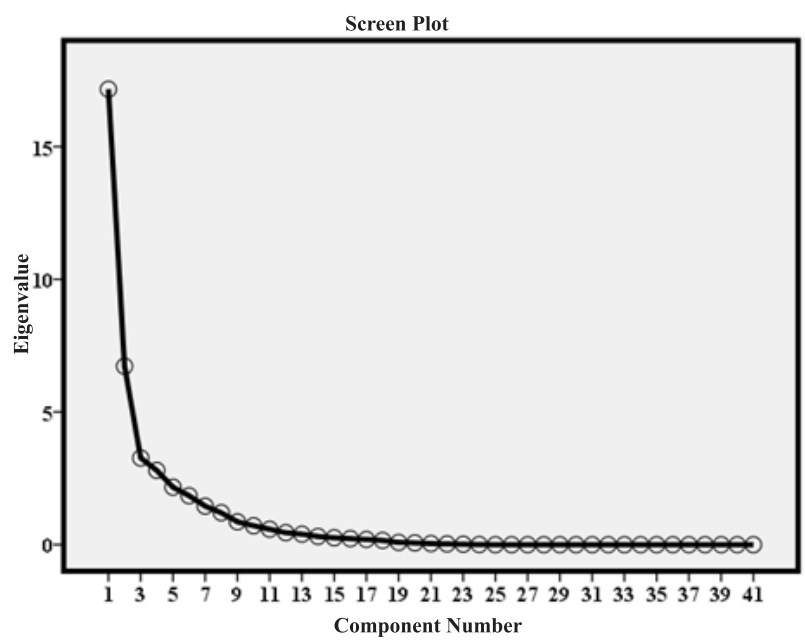

Fig. 5. Screen plot showing visual representation of factor analysis of elements in the Bogacayi riverbank sediments. 
Table 6. Result of factor analysis of heavy elements in Bogacayi riverbank sediments (component matrix ${ }^{\mathrm{a}}$ ).

\begin{tabular}{|c|c|c|c|c|c|c|}
\hline & \multicolumn{6}{|c|}{ Component } \\
\hline & 1 & 2 & 3 & 4 & 5 & 6 \\
\hline $\mathrm{Ti}$ & .927 & .104 & .129 & .236 & -.071 & .100 \\
\hline $\mathrm{Al}$ & .919 & -.123 & -.051 & -.219 & .149 & -.132 \\
\hline $\mathrm{Y}$ & .911 & -.272 & -.075 & .186 & -.014 & -.050 \\
\hline $\mathrm{Ta}$ & .905 & -.293 & -.006 & .104 & -.181 & .111 \\
\hline $\mathrm{Hf}$ & .902 & -.310 & -.020 & .033 & -.096 & .026 \\
\hline $\mathrm{Zr}$ & .901 & -.368 & -.053 & .060 & -.156 & .027 \\
\hline $\mathrm{Ce}$ & .898 & -.403 & -.121 & .047 & -.027 & -.027 \\
\hline $\mathrm{Nb}$ & .895 & -.283 & .000 & .160 & -.229 & .074 \\
\hline $\mathrm{K}$ & .890 & -.362 & -.087 & -.113 & .139 & -.109 \\
\hline $\mathrm{La}$ & .882 & -.405 & -.091 & .105 & -.071 & -.010 \\
\hline $\mathrm{P}$ & .851 & -.385 & -.042 & .200 & -.079 & .035 \\
\hline $\mathrm{Na}$ & .816 & -.014 & -.290 & .035 & .332 & -.249 \\
\hline $\mathrm{Zn}$ & .799 & .241 & .292 & -.122 & -.229 & .077 \\
\hline W & .799 & -.121 & -.103 & -.106 & -.203 & .042 \\
\hline $\mathrm{Fe}$ & .788 & .585 & -.015 & -.032 & -.038 & .140 \\
\hline $\mathrm{Li}$ & .780 & -.301 & .099 & -.401 & .166 & -.079 \\
\hline $\mathrm{Ba}$ & .777 & .196 & .154 & .155 & -.098 & .235 \\
\hline $\mathrm{V}$ & .736 & .589 & .112 & .116 & -.088 & .083 \\
\hline $\mathrm{Cu}$ & .722 & .275 & .125 & -.454 & -.098 & -.079 \\
\hline $\mathrm{Rb}$ & .704 & -.558 & .069 & -.329 & .021 & -.197 \\
\hline $\mathrm{Mn}$ & .632 & .459 & -.024 & .443 & -.152 & .066 \\
\hline $\mathrm{Co}$ & .570 & .730 & -.112 & -.254 & .052 & .126 \\
\hline $\mathrm{Sn}$ & .552 & -.375 & .522 & .229 & -.048 & -.067 \\
\hline $\mathrm{Sc}$ & .514 & .671 & .056 & .255 & .086 & -.057 \\
\hline $\mathrm{U}$ & .370 & -.055 & -.517 & -.027 & .316 & .212 \\
\hline $\mathrm{Ni}$ & .341 & .697 & -.333 & -.323 & -.018 & .010 \\
\hline $\mathrm{Mg}$ & .330 & .710 & -.209 & -.274 & .144 & .273 \\
\hline $\mathrm{Sb}$ & .298 & .239 & .782 & .201 & .286 & -.064 \\
\hline $\mathrm{Cr}$ & .298 & .722 & .282 & .026 & -.103 & .398 \\
\hline $\mathrm{Cd}$ & .277 & .546 & .428 & .371 & .072 & -.218 \\
\hline In & .251 & -.145 & .454 & -.233 & .451 & -.352 \\
\hline $\mathrm{Th}$ & .172 & -.772 & .307 & -.296 & .012 & .364 \\
\hline $\mathrm{Bi}$ & .127 & .181 & .784 & .182 & .390 & -.153 \\
\hline Mo & .108 & -.087 & .345 & -.299 & .151 & .527 \\
\hline $\mathrm{Ag}$ & -.001 & -.080 & -.424 & .239 & .545 & .099 \\
\hline $\mathrm{Te}$ & -.040 & .084 & -.017 & .128 & -.514 & -.509 \\
\hline $\mathrm{Sr}$ & -.082 & -.300 & -.142 & .806 & .200 & .129 \\
\hline As & -.232 & .470 & .213 & -.326 & -.248 & -.311 \\
\hline $\mathrm{Au}$ & -.497 & -.327 & .253 & -.256 & -.283 & .056 \\
\hline $\mathrm{Pb}$ & -.554 & -.463 & .499 & -.235 & -.011 & .354 \\
\hline $\mathrm{Ca}$ & -.728 & -.206 & .159 & .499 & -.231 & .214 \\
\hline
\end{tabular}

Extraction Method: Principal Component Analysis.

a. 6 components extracted. 


\begin{tabular}{|c|c|c|c|c|c|c|c|c|c|c|c|c|c|c|c|c|c|c|c|}
\hline $\begin{array}{c}\text { Variation of average } \\
\text { concentration in Alanya- } \\
\text { Manavgat beach sand }(\mathrm{A} / \mathrm{K})\end{array}$ & $\stackrel{ \pm}{\rightarrow}$ & $\stackrel{+}{-}$ & $\begin{array}{l}\overrightarrow{0} \\
i\end{array}$ & $\stackrel{\tilde{r}}{\sim}$ & $\stackrel{尺}{i}$ & 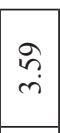 & $\hat{\tilde{n}}$ & $\begin{array}{l}\stackrel{\infty}{\infty} \\
\stackrel{0}{2}\end{array}$ & $\stackrel{n}{n}$ & $\stackrel{3}{0}$ & $\tilde{\Omega}$ & $\stackrel{\infty}{\stackrel{\infty}{-}}$ & $\stackrel{n}{0}$ & & 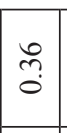 & ले & $\stackrel{9}{\leftrightarrows}$ & $\stackrel{\hat{i}}{i}$ & $\stackrel{ \pm}{\rightarrow}$ \\
\hline $\begin{array}{c}\text { Alanya-Manavgat, Mean } \\
{[34](\mathrm{K})}\end{array}$ & 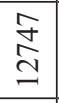 & 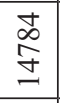 & $\begin{array}{l}\infty \\
\tilde{\hat{\Omega}} \\
\vdots\end{array}$ & જิ & $\stackrel{\infty}{n}$ & $\stackrel{m}{=}$ & 은 $+x+1$ & 2 & 0 & r & $\approx$ & 0 & $=$ & 1 & $\sim$ & - & 0 & 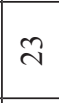 & 0 \\
\hline $\begin{array}{l}\text { Variation of average } \\
\text { concentration in Silifke- } \\
\text { Alanya Beach }(\mathrm{A} / \mathrm{J})\end{array}$ & $\stackrel{\infty}{\leftrightarrows}$ & $\stackrel{\sim}{\sim}$ & $\stackrel{\infty}{\stackrel{\infty}{i}}$ & $\stackrel{\sim}{m}$ & 齐 & $\begin{array}{l}: \\
\stackrel{0}{0} \\
\dot{1}\end{array}$ & $\stackrel{+}{\stackrel{i}{i}}$ & $\underset{\substack{\infty\\
}}{\stackrel{\infty}{n}}$ & $\begin{array}{l}\hat{\sigma} \\
+\end{array}$ & $\bar{n}$ & $\stackrel{n}{\rightarrow}$ & $\stackrel{\beta}{\beta}$ & $\stackrel{\vec{\sigma}}{\circ}$ & $\stackrel{g}{-}$ & $\stackrel{?}{\stackrel{2}{-}}$ & $\stackrel{ \pm}{0}$ & \begin{tabular}{l}
0 \\
\multirow{0}{0}{}
\end{tabular} & 品 & $\stackrel{9}{9}$ \\
\hline $\begin{array}{c}\text { Silifke-Alanya Beach } \\
\text { sediman Mean [33] (J) }\end{array}$ & 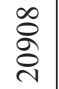 & $\begin{array}{l}\vec{n} \\
\vdots \\
n\end{array}$ & $\begin{array}{l}\infty \\
\stackrel{\alpha}{\sigma}\end{array}$ & f & $\stackrel{n}{m}$ & $\simeq$ & $a$ & $\cong$ & in & $a$ & હे & 0 & $a$ & 0 & - & 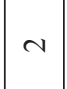 & - & $\stackrel{\infty}{\sim}$ & 0 \\
\hline $\begin{array}{c}\text { Variation of average } \\
\text { concentration in Mersin } \\
\text { Bay (A/I) }\end{array}$ & $\begin{array}{l}\vec{\infty} \\
0\end{array}$ & $\begin{array}{l} \pm \\
\infty \\
0\end{array}$ & $\stackrel{\beth}{=}$ & $\stackrel{0}{0}$ & $\stackrel{8}{0}$ & $\begin{array}{l}8 \\
0 \\
0\end{array}$ & $\stackrel{8}{0}$ & $\stackrel{8}{\circ}$ & $\stackrel{8}{\circ}$ & $\stackrel{8}{0}$ & $\stackrel{8}{\circ}$ & $\stackrel{8}{0}$ & $\stackrel{8}{0}$ & & . & & ' & & ' \\
\hline $\begin{array}{c}\text { Mersin Bay Beach sediman } \\
\text { Mean [10] (I) }\end{array}$ & 赤 & $\begin{array}{l}\infty \\
\stackrel{\infty}{5} \\
\vdots \\
⿱ 亠 乂\end{array}$ & 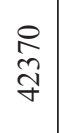 & $\underset{\sim}{\stackrel{2}{\sim}}$ & \begin{tabular}{l}
8 \\
8 \\
0 \\
0 \\
\hdashline \\
1
\end{tabular} & 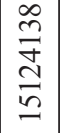 & 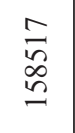 & $\begin{array}{l}\text { à } \\
\text { ลे } \\
\text { ลे }\end{array}$ & 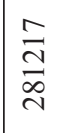 & 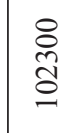 & 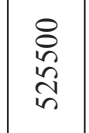 & $\stackrel{\bar{\lambda}}{\sim}$ & $\begin{array}{l}M \\
\infty \\
\infty \\
\infty\end{array}$ & & ' & & ' & ' & ' \\
\hline $\begin{array}{c}\text { Variation of average } \\
\text { concentration in İskenderun } \\
\text { Bay }(\mathrm{A} / \mathrm{H}) \\
\end{array}$ & 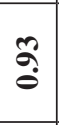 & 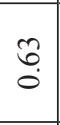 & $\tilde{n}$ & $\stackrel{\overbrace{}}{\rightarrow}$ & $\stackrel{9}{\circ}$ & 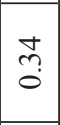 & $\stackrel{\text { g }}{-}$ & $\hat{n}$ & $\begin{array}{l}\infty \\
n \\
0\end{array}$ & $\overline{\tilde{o}}$ & f. & $\stackrel{0}{\stackrel{0}{0}}$ & $\stackrel{\infty}{\tilde{c}}$ & $\stackrel{\simeq}{=}$ & $\mid \begin{array}{l}0 \\
0 \\
0\end{array}$ & $\tilde{2}$ & 导 & $\stackrel{n}{n}$ & $\stackrel{\infty}{\sim}$ \\
\hline $\begin{array}{l}\text { İskenderun Bay Beach } \\
\text { sediman Mean [35] })(\mathrm{H})\end{array}$ & $\begin{array}{l}\text { 足 } \\
\text { d. } \\
\text { N }\end{array}$ & $\frac{\mathfrak{m}}{\tilde{q}}$ & $\begin{array}{l}8 \\
\cdots \\
\kappa\end{array}$ & $\underset{d}{\stackrel{d}{d}}$ & 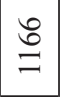 & $\stackrel{\infty}{\infty}$ & $\stackrel{0}{-1}$ & 过 & q & 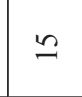 & ஓ & 0 & 은 & 0 & - & 0 & - & $\Xi$ & - \\
\hline $\begin{array}{c}\text { Variation of average } \\
\text { concentration in Susanoglu } \\
\text { Beach dune (A/G) }\end{array}$ & $\stackrel{\infty}{\stackrel{i}{i}}$ & $\stackrel{\text { ¿̊ }}{\text { i }}$ & $\stackrel{I}{m}$ & $\underset{+}{\tilde{+}}$ & $\underset{m}{ \pm}$ & $\hat{a}$ & $\stackrel{\text { gे }}{-}$ & $\stackrel{+}{\stackrel{n}{n}}$ & 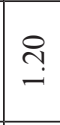 & $\hat{o}$ & $\underset{i}{\stackrel{J}{i}}$ & $\stackrel{\circ}{\circ}$ & กิ & 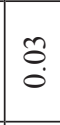 & $\tilde{O}$ & $\begin{array}{l}t \\
0 \\
0\end{array}$ & $\begin{array}{l}\infty \\
0 \\
0\end{array}$ & $\stackrel{?}{=}$ & $\hat{o}$ \\
\hline $\begin{array}{c}\text { Susanoglu Beach sediman } \\
\text { Mean }[9](\mathrm{G})\end{array}$ & $\begin{array}{l}\stackrel{\Xi}{\Xi} \\
\stackrel{\Xi}{\exists}\end{array}$ & ڤे & 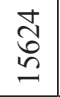 & $\stackrel{2}{\sim}$ & m & $\stackrel{\infty}{\sim}$ & $\simeq$ & $\stackrel{q}{g}$ & $\vec{N}$ & n & $\simeq$ & + & 2 & $\theta$ & $\hat{\imath}$ & in & $n$ & $\infty$ & 6 \\
\hline $\begin{array}{r}\text { Variation of a } \\
\text { concentration in } \\
\text { Beach dune } \\
\end{array}$ & $\stackrel{8}{\dot{m}}$ & $\stackrel{n}{n}$ & $\stackrel{\text { I }}{-}$ & 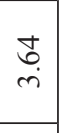 & $\stackrel{શ}{i}$ & $\stackrel{2}{0}$ & $\stackrel{\infty}{\substack{i \\
i}}$ & $\stackrel{\infty}{\stackrel{\leftrightarrow}{-}}$ & \&. & $\cong$ & $\stackrel{\infty}{\vec{i}}$ & $\stackrel{0}{\circ}$ & $\stackrel{0}{\circ}$ & $\stackrel{8}{0}$ & $\tilde{O}$ & $\begin{array}{l} \pm \\
0 \\
0\end{array}$ & $\begin{array}{l}0 \\
0 \\
0\end{array}$ & $\stackrel{\sigma}{\sigma}$ & $\stackrel{8}{\circ}$ \\
\hline $\begin{array}{c}\text { Kizkalesi Beachsediman } \\
\text { Mean }[26](\mathrm{F})\end{array}$ & ஸ્ळ & $\begin{array}{l}m \\
\infty \\
\infty \\
\infty\end{array}$ & 㑒 & $\frac{m}{\infty}$ & $\stackrel{\infty}{\infty}$ & $\hat{n}$ & 으 & $\stackrel{\infty}{-}$ & $\stackrel{\infty}{i}$ & ナ & 2 & $\checkmark$ & $\stackrel{\sim}{\sim}$ & t & $\approx$ & in & $\infty$ & 3 & $r$ \\
\hline $\begin{array}{c}\text { Variation of average } \\
\text { concentration in TKKY } \\
\text { (fold) (A/E) }\end{array}$ & & ' & ' & ' & ' & $\begin{array}{l}n \\
\stackrel{n}{+}\end{array}$ & 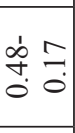 & $\begin{array}{ll}\hat{A} & \bar{\gamma} \\
\text { İ } & \end{array}$ & Iִ & ठ․ & $\mid$\begin{tabular}{ll}
1 & 0 \\
\hdashline & $\vdots$ \\
0 & 0 \\
0
\end{tabular} & त่̂ & $\frac{\partial}{0}$ & & $\stackrel{0}{\circ}$ & & $\stackrel{\ddot{o}}{\circ}$ & & ' \\
\hline $\begin{array}{l}\text { Acceptable limit for Turkey } \\
(\mathrm{mg} / \mathrm{kg})[31](\mathrm{E})\end{array}$ & & ' & ' & ' & ' & $\begin{array}{l}8 \\
\stackrel{\vdots}{\circ}\end{array}$ & 竞 & in & $\stackrel{8}{\circ}$ & 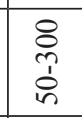 & 官 & ب़ें & $\stackrel{8}{\circ}$ & & $\stackrel{8}{0}$ & & $\stackrel{8}{\circ}$ & & ' \\
\hline $\begin{array}{c}\text { Variation of average } \\
\text { concentration in Ultrabasic } \\
\text { (fold) (A/D) }\end{array}$ & $\stackrel{\mathbb{I}}{\rightarrow}$ & ల్ల. & 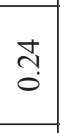 & $\begin{array}{l}\infty \\
\infty \\
\sigma\end{array}$ & : & ๙ุ & $\stackrel{\infty}{\underset{i}{i}}$ & $\stackrel{\infty}{\circ}$ & $\stackrel{1}{0}$ & $\begin{array}{l}8 \\
\dot{+}\end{array}$ & $\begin{array}{l}\infty \\
0 \\
0\end{array}$ & ñ & $\stackrel{\mathbb{i}}{i}$ & $\stackrel{\infty}{\infty}$ & $\stackrel{\curvearrowright}{-}$ & $\begin{array}{l}\infty \\
\stackrel{0}{0} \\
i\end{array}$ & $\underset{\Xi}{ \pm}$ & $\underset{\leftarrow}{-}$ & हn \\
\hline Ultrabasic [30] (D) & ڤั̀े & $\begin{array}{l}8 \\
\stackrel{0}{\$} \\
2\end{array}$ & $\begin{array}{l}\text { ò } \\
\vdots \\
\stackrel{1}{4}\end{array}$ & \&্ల & $\underset{్ ర ి}{~}$ & $\underset{0}{8}$ & 으 & ષ્ণ & $\stackrel{n}{n}$ & - & in & - & - & 0 & 0 & 0 & - & P & - \\
\hline $\begin{array}{l}\text { Variation of average } \\
\text { concentration in Sanstone } \\
\text { (fold) }(\mathrm{A} / \mathrm{C})\end{array}$ & g్ & $\stackrel{\check{i}}{i}$ & $\underset{\circ}{\stackrel{8}{r}}$ & S. & $\stackrel{8}{:}$ & $\stackrel{n}{=}$ & $\begin{array}{l}\tilde{b} \\
i \\
i\end{array}$ & $\begin{array}{l}\infty \\
\stackrel{\infty}{+} \\
\dot{+} \\
\infty\end{array}$ & $\underset{\substack{2 \\
\infty}}{\stackrel{\infty}{\infty}}$ & 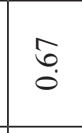 & ते & $\hat{n}$ & $\stackrel{N}{\stackrel{N}{n}}$ & $\stackrel{\mathbb{J}}{\underset{I}{(}}$ & $\begin{array}{l}\stackrel{2}{2} \\
\text { in }\end{array}$ & $\overrightarrow{\vec{i}}$ & $\begin{array}{l}0 \\
0 \\
0\end{array}$ & $\stackrel{\ddot{n}}{\ddot{n}}$ & ๙ุ \\
\hline Sanstone [30] (C) & 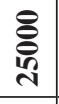 & $\begin{array}{l}8 \\
\infty \\
\infty\end{array}$ & ঃ & \begin{tabular}{l}
8 \\
\hdashline \\
\hdashline
\end{tabular} & 8 & $m$ & $a$ & N & 0 & r & $\stackrel{0}{-}$ & 0 & - & 0 & 0 & 0 & - & ণ & N \\
\hline $\begin{array}{c}\text { Variation of average } \\
\text { concentration in Earth crust } \\
\text { (fold) }(\mathrm{A} / \mathrm{B})\end{array}$ & $\overrightarrow{3}$ & $\tilde{n}$ & $\begin{array}{c}0 \\
\stackrel{1}{i}\end{array}$ & กี & $\underset{-}{\stackrel{ \pm}{-}}$ & $\begin{array}{l}n \\
\stackrel{n}{+} \\
\dot{+}\end{array}$ & $\stackrel{\infty}{\leftarrow}$ & $\vec{\sigma}$ & ְִ & $\hat{n}$ & nิ & $\stackrel{\sim}{\sim}$ & $\hat{\mathrm{i}}$ & $\stackrel{8}{-}$ & ஸे & $\underset{-}{\stackrel{\Xi}{-}}$ & $\tilde{\jmath}$ & in & $\stackrel{m}{2}$ \\
\hline Earth crust (mg/kg) [29] (B) & $\stackrel{ి}{\infty}$ & $\begin{array}{l}8 \\
\vdots \\
\vdots \\
1 \\
\end{array}$ & ষ্ণ & 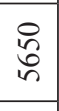 & 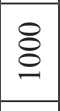 & 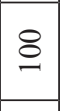 & in & 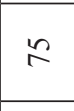 & ¿ & 9 & 8 & 0 & N & 0 & N & 0 & $m$ & $\cong$ & - \\
\hline Bogacay mean & 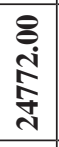 & $\begin{array}{l}8 \\
8 \\
\dot{0} \\
\infty \\
\infty \\
i \\
\end{array}$ & $\begin{array}{l}8 \\
8 \\
\dot{8} \\
\stackrel{0}{\circ} \\
\stackrel{+}{+}\end{array}$ & $\begin{array}{l}8 \\
\text { a } \\
\text { aิ } \\
\end{array}$ & $\begin{array}{l}0 \\
\text { r } \\
\stackrel{+}{+} \\
\stackrel{0}{0}\end{array}$ & $\begin{array}{l}\dot{J} \\
\text { d } \\
\dot{q}\end{array}$ & $\begin{array}{l}\tilde{\infty} \\
\tilde{\sim}\end{array}$ & $\begin{array}{l}0 \\
\cdots \\
\infty \\
0 \\
\infty\end{array}$ & $\underset{m}{3}$ & $\begin{array}{l}\stackrel{8}{\circ} \\
\stackrel{+}{ }\end{array}$ & 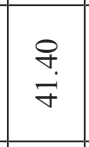 & $\tilde{\overbrace{}}$ & $\underset{\sim}{\mathbb{n}}$ & $\overrightarrow{0}$ & : & $\overrightarrow{\widetilde{\sigma}}$ & $\begin{array}{l}\tilde{n} \\
0\end{array}$ & $\begin{array}{l}\text { 足 } \\
\text { did }\end{array}$ & ले \\
\hline & « & 芒 & $\sum^{\infty}$ & $F$ & $\sum_{2}^{5}$ & U゙ & $\tilde{J}$ & $\bar{z}$ & 8 & 2 & งี & $\tilde{U}$ & \& & $\stackrel{50}{4}$ & $\stackrel{0}{\Sigma}$ & की & है & $>$ & 3 \\
\hline
\end{tabular}


Table 8. Comparison of high anomaly concentrations of some elements in the sample with earth crust, sandstone, ultrabasic rock, and acceptable limits for Turkey.

\begin{tabular}{|c|c|c|c|c|c|c|c|c|c|c|}
\hline 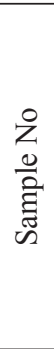 & 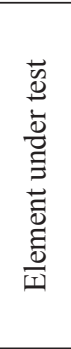 & 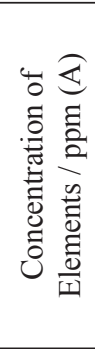 & 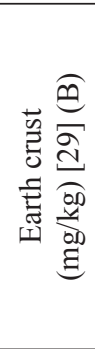 & 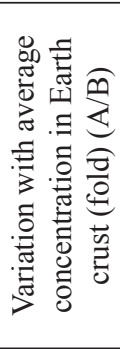 & $\begin{array}{l}0 \\
0 \\
0 \\
0 \\
0 \\
0 \\
0 \\
\tilde{n} \\
\tilde{E} \\
\tilde{n}\end{array}$ & 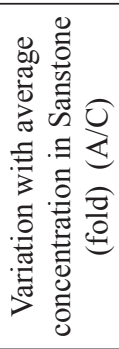 & $\begin{array}{l}\widehat{\ominus} \\
0 \\
0 \\
0 \\
0 \\
0 \\
0 \\
0 \\
0 \\
0 \\
0\end{array}$ & 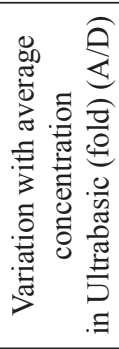 & 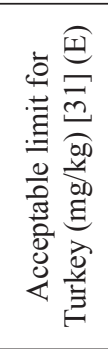 & 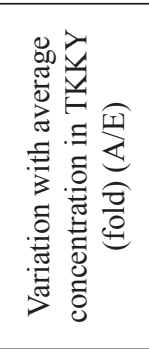 \\
\hline 1 & $\mathrm{~Pb}$ & 11.4 & 2.5 & 4.56 & 7 & 1.63 & 1 & 11.40 & $50-300$ & $<1$ \\
\hline 10 & $\mathrm{Mn}$ & 1435 & 1000 & 1.44 & 90 & 15.94 & 1620 & 0.89 & - & - \\
\hline 24 & $\mathrm{Mn}$ & 1350 & 1000 & 1.35 & 90 & 15.00 & 1620 & 0.83 & - & - \\
\hline 4 & As & 6 & 1.8 & 3.33 & 1 & 6.00 & 1 & 6.00 & 20 & 0.30 \\
\hline 5 & As & 8 & 1.8 & 4.44 & 1 & 8.00 & 1 & 8.00 & 20 & 0.40 \\
\hline 16 & $\mathrm{Ag}$ & 0.2 & 0.07 & 2.86 & 0.09 & 2.22 & 0.06 & 3.33 & - & - \\
\hline 18 & $\mathrm{Ag}$ & 0.2 & 0.07 & 2.86 & 0.09 & 2.22 & 0.06 & 3.33 & - & - \\
\hline 24 & Co & 37.3 & 20 & 1.87 & 0.3 & 124.33 & 150 & 0.25 & 20 & 1.87 \\
\hline 25 & $\mathrm{Co}$ & 37 & 20 & 1.85 & 0.3 & 123.33 & 150 & 0.25 & 20 & 1.85 \\
\hline 24 & $\mathrm{Fe}$ & 42500 & 54000 & 0.79 & 9800 & 4.34 & 94300 & 0.45 & - & - \\
\hline 25 & $\mathrm{Fe}$ & 37500 & 54000 & 0.69 & 9800 & 3.83 & 94300 & 0.40 & - & - \\
\hline 24 & $\mathrm{~V}$ & 118 & 110 & 1.07 & 20 & 5.90 & 40 & 2.95 & - & - \\
\hline 24 & $\mathrm{Cr}$ & 1985 & 100 & 19.85 & 35 & 56.71 & 1600 & 1.24 & 100 & 19.85 \\
\hline 24 & $\mathrm{Mg}$ & 68800 & 23000 & 2.99 & 7000 & 9.83 & 204000 & 0.34 & - & - \\
\hline 25 & $\mathrm{Mg}$ & 81600 & 23000 & 3.55 & 7000 & 11.66 & 204000 & 0.40 & - & - \\
\hline 25 & $\mathrm{Ni}$ & 578.6 & 75 & 7.71 & 2 & 289.30 & 2000 & 0.29 & $30-75$ & $19.29-7.71$ \\
\hline
\end{tabular}

When the anomaly concentrations of these elements in the mentioned samples were compared to the mean value of the earth crust, $\mathrm{Pb}$ (4.56-fold) in $\mathrm{S} 1, \mathrm{Mn}$ (1.44fold) in S10, Mn (1.35 fold) in S24, As (3.33-fold) in S4, As (4.44-fold) in S5, Ag (2.86-fold) in S16 and S18, Co (1.87-fold) in S24, Co (1.85-fold) in S25, V (1.07-fold) in $\mathrm{S} 24, \mathrm{Cr}$ (19.85-fold) in S24, Mg (2.99-fold) in $\mathrm{S} 24, \mathrm{Mg}$ (3.55-fold) in S25, and Ni (7.71-fold) in S25 have higher concentrations. When compared to their mean values in Sandstone, $\mathrm{Pb}$ (1.63-fold) in $\mathrm{S} 1, \mathrm{Mn}$ (15.94-fold) in S10, Mn (15-fold) in S24, As (6-fold) in S4, As (8-fold) in S5, $\mathrm{Ag}$ (2.22-fold) in S16 and S18, Zn (3.44-fold) in S24, Co (124.33-fold) in S25, Co (123.33-fold) in S25, Fe (4.34fold) in S24, Fe (3.83-fold) in S25, V (5.90-fold) in S24, $\mathrm{Cr}$ (56.71-fold) in S24, Mg (9.83-fold) in S24, Mg (11.66fold) in S24, and Ni (289.3-fold) S25. When compared to their mean values in Ultrabasic, $\mathrm{Pb}$ (11.4-fold) in $\mathrm{S} 1$, As (6-fold) in S4, As (8-fold) in S5, Ag (3.33-fold) in S16 and S18, Zn (1.10-fold) in S24, V (2.95-fold) in S24, and $\mathrm{Cr}$ (1.24-fold) in S24. When compared to their acceptable limit for Turkey, Co (1.87-fold) in S24, Co (1.85-fold) in S25, and Cr (19.85-fold) in S24 and Ni (19.29-7.71fold) are greater. Reference values for $\mathrm{Ba}$ and $\mathrm{Zr}$ were not available (Table 8).

\section{Discussion}

From the comparison in Table 8, it is worth noting the very high anomaly concentration of $\mathrm{Cr}$ in sample 24 is 19.85 times and Ni in sample 25 is 19.29-7.71 times higher than the acceptable limits in Turkey. These proportions are very high and confirm the need for a close study of heavy elements around the localities of samples 24 and 25 , alongside $\mathrm{Co}$, which is 1.87 - and 1.85 -fold greater than the acceptable limit for Turkey in samples 24 and 25, respectively. The acceptable Turish limits for (Mn, Ag, Fe, $\mathrm{V}$, and $\mathrm{Mg}$ ) were not available.

According to the box plot analyzed above, samples 24 and 25 have high anomalous concentrations of some heavy metal elements that are both grouped in the second cluster in the Hierarchical Cluster analysis. Some samples in other clusters do have anomalies in identical heavy metal elements such as cluster 3 (S 4 and 5) with high As anomaly and cluster 4 (S 8, 19, and 23) with low Sb anomaly. This is thought to be an indicator to confirm the similarities of the samples.

Both the coefficient correlation and PCA confirm the negative relationship of $\mathrm{Pb}$ and $\mathrm{As}$ with the other elements under investigation $(\mathrm{Mg}, \mathrm{Fe}, \mathrm{Al}, \mathrm{Ti}, \mathrm{Mn}, \mathrm{Cr}, \mathrm{Ni}, \mathrm{Ba}, \mathrm{V}$, 
$\mathrm{Zr}, \mathrm{Zn}, \mathrm{Co}, \mathrm{Cu}, \mathrm{Mo}, \mathrm{W}, \mathrm{Cd}, \mathrm{Sb}$, and $\mathrm{Ag}$ ) in Component 1. This is further confirmed by the box plot. In sample 1, $\mathrm{Pb}$ has an anomalous high concentration whereas there's a corresponding decrease in $\mathrm{Cu}, \mathrm{Zn}, \mathrm{Ni}, \mathrm{Co}, \mathrm{Mn}, \mathrm{Fe}, \mathrm{V}, \mathrm{Ba}$, $\mathrm{Ti}, \mathrm{Al}, \mathrm{W}$, and $\mathrm{Zr}$ in the same sample. Similarly, in sample 5, as As increases, $\mathrm{Zn}, \mathrm{Ba}, \mathrm{Ti}, \mathrm{W}, \mathrm{Zr}$, and $\mathrm{Al}$ decrease. $\mathrm{Mg}$, Fe, Al, Ti, Mn, Cr, Ni, Ba, V, Zr, Zn, Co, Cu, Mo, W, Cd, and $\mathrm{Sb}$ show a positive relationship with each other. From this analysis, metals that have strong positive correlation are thought to be of the same source, while those of strong negative correlations are thought to be of a different origin.

According to [9, 32-35], component 1 is usually allocated to be the geogenic source, component 2 the anthropogenic activities related, and component 3 the anthropogenic source. Most of the Ti, Al, Zr, Zn, W, Ba, and $\mathrm{Cu}$, and the majority of $\mathrm{Fe}, \mathrm{V}, \mathrm{MN}$, and $\mathrm{Sn}$ are thought to have come from a natural source. Most of the $\mathrm{Ni}, \mathrm{Mg}$, $\mathrm{Cr}$, and $\mathrm{As}$, and the majority of the $\mathrm{Co}$ and $\mathrm{Cd}$ are thought to have resulted from both natural and anthropogenicrelated activities, implying no clear distinction of a particular source by the PCA. Most of the Sb, Mo, and $\mathrm{Pb}$ are believed to have come from anthropogenic activities. Though the majority of the Fe, V, MN, and Sn are thought to have come from a natural source, and Co and $\mathrm{Cd}$ from natural and anthropogenic-related activities, a considerable quantity of the elements are also thought to have been contributed from other sources such as: natural (Co), natural and anthropogenic-related activities (Fe, V, $\mathrm{MN}$, and $\mathrm{Sn}$ ), and anthropogenic activities ( $\mathrm{Sn}$ and $\mathrm{Cd}$ ).

The heavy metal elements ( $\mathrm{Sb}, \mathrm{Mo}$, and $\mathrm{Pb}$ ) that are well loaded in component 3 do not show a good correlational relationship according to Pearson's correlation, whereas those with high values (well loaded) in the first component demonstrate either a strong or stronger correlational relationship among themselves, and to some in the second component such as Fe, V, and Mn, according to Pearson's correlation. Base on this, such elements are thought to have a possible related source.

Samples 24 (Zn, Co, Mn, Fe, V, Cr, Mg, and Ba) and $25(\mathrm{Ni}, \mathrm{Co}, \mathrm{Fe}$, and $\mathrm{Mg}$ ) contain several numbers of heavy metals, each showing high anomalous concentrations, that are related to anthropogenic sources based on the PCA (Table 6).

\section{Conclusion}

From the results and discussion above, it can be concluded that the abundance of the elements under investigation are as follows: $\mathrm{Mg}>\mathrm{Fe}>\mathrm{Al}>\mathrm{Ti}>\mathrm{Mn}>\mathrm{Cr}$ $>\mathrm{Ni}>\mathrm{Ba}>\mathrm{V}>\mathrm{Zr}>\mathrm{Zn}>\mathrm{Co}>\mathrm{Cu}>\mathrm{Pb}>\mathrm{As}>\mathrm{Mo}>\mathrm{W}$ $>\mathrm{Cd}>\mathrm{Sb}>\mathrm{Ag}$.

A sufficient number of samples and elements from the study area were used in this analysis based on the high explanatory power $\mathrm{R}^{2}=100.00 \%$ of 24 descriptive elements on Al, according to the ANOVA model summary.

Anthropogenic activities contributed most of the Sb, $\mathrm{Mo}$, and $\mathrm{Pb}$, and led to an increase in the quantities of elements such as $\mathrm{Fe}, \mathrm{V}, \mathrm{Mn}, \mathrm{Co}, \mathrm{Ni}, \mathrm{Mg}, \mathrm{Cr}$, and $\mathrm{As}$.
Samples 24 (Zn, Co, Mn, Fe, V, Cr, Mg, and Ba) and 25 (Ni, Co, Fe, and $\mathrm{Mg}$ ) contain several numbers of heavy metals, each showing high anomalous concentrations that are related to anthropogenic sources. The concentration of $\mathrm{Cr}$ in sample 24 is 19.85 times and $\mathrm{Ni}$ in sample 25 is 19.29-7.71 times higher than the acceptable limits for Turkey. These proportions are very high and confirm the need for a close study of heavy elements around the localities of samples 24 and 25; alongside Co this is 1.87 and 1.85-fold greater than the acceptable limits for Turkey in samples 24 and 25 , respectively.

In comparison to the average concentration in the earth's crust, average concentrations for $\mathrm{Mg}$ (2.16 times), $\mathrm{Mn}$ (1.04 times), Cr (4.05 times), NI (4.91 times), Co (1.26 times), Cd (1.52 times), As (2.07 times), Ag (1.6 times), and $\mathrm{Sb}$ (1.04 times) were greater. Compared to the sandstone average concentration, Fe (2.93 times), $\mathrm{Mg}$ (7.09 times), Ti (1.97 times), Mn (11.6 times), $\mathrm{Cr}$ (11.57 times), $\mathrm{Cu}$ (2.65 times), Ni (184.08 times), Co (83.76 times), Zn (2.59 times), Cd (2.53 times), As (3.72 times), $\mathrm{Ag}$ (1.24 times), Mo (2.9 times), $\mathrm{Sb}$ (2.31 times), and V (3.23 times) had higher average concentrations. Average concentrations of Al (1.24 times), Ti (9.86 times), $\mathrm{Cu}$ (2.38 times), $\mathrm{Pb}$ (4.66 times), As (3.72 times), Ag (1.87 times), Mo (1.93 times), $\mathrm{Sb}$ (2.08 times), Sn (1.14 times), and V (1.61 times) were greater than those of ultrabasic, and when compared to the acceptable limit for Turkey, $\mathrm{Cr}$ (4.05 times), Co (1.26 times), and $\mathrm{Ni}$ (12.27-4.91 times) had greater concentrations.

Six (6) factors were retained by factor analysis and they represent a very high proportion of $83.949 \%$ of the variables' variance of analyzed elements.

\section{Acknowledgements}

This study contains part of a scientific research project (2013.01.0102.003) of Akdeniz University. The financial support of the Scientific Research Projects Unit of Akdeniz University is gratefully acknowledged.

\section{References}

1. DANG Z., LIU C., HAIG M.J. Mobility of heavy metals associated with the natural weathering of coal mine spoils. Environmental Pollution, 118 (3), 419, 2002.

2. OBIAJUNWA E.I, PELEMO D.A, OWALABI S.A, FASAI M.K., JOHNSON-F FATOKUN F.O. Characterization of heavy metal pollutants of soils and sediments around a Crudefoil production terminal using EDXRF. Nucl. Instr. Methods Phys B., 194, 61, 2002.

3. TAM N.F.Y., WONG Y.S. Spatial variation of heavy metals in surface sediments of Hong Kong mangrove swamps. Environmental Pollution, 110, 195, 2000.

4. Lenntech Water Treatment and Air Purification. Water Treatment, Published by Lenntech, Rotterdamseweg, Netherlands (www.excelwater.com/thp/filters/WaterPurification.htm), 2004.

5. DURUIBE J.O., OGWUEGBU M.O.C., EGWURUGWU J.N. Heavy metal pollution and human biotoxic effects. 
International Journal of Physical Sciences, 2 (5), 112, 2007.

6. RAJU K.V., SOMASHEKAR R., PRAKASH K., Heavy Metal Status of Sediment in River Cauvery, Karnataka. Environmental Monitoring and Assessment, 184 (1), 361, 2012, doi:10.1007/s10661-011-1973-2

7. CHAKRAVARTY M., PATGIRI A. Metal Pollution Assessment in Sediments of the Dikrong River, N. E. India. Journal of Human Ecology, 27 (1), 63, 2009.

8. DINIS M.D.L., FIÚZA A. Exposure Assessment To Heavy Metals In The Environment: Measures To Eliminate Or Reduce The Exposure To Critical Receptors. GeoEnvironment and Resources Research Center (CIGAR), Faculty of Engineering, University of Porto, 2011.

9. YALCIN M.G. Heavy minerals distribution as related to environmental conditions for modern beach sediments from the Susanoglu (Atakent, Mersin, Turkey). Environ. Geol., 58, 119, 2009.

10. YALCIN M.G., CEVIK O., KARAMAN M.E. The use of multivariate statistics methods to determine grain size, heavy metal distribution and origins of heavy metals in Mersin Bay (Eastern Mediterranean) Coastal Sediments. Asian Journal of Chemistry, 25 (5), 2696, 2013.

11. DUZZIN B., PAVONI B., DONAZOLO R. Macroinvertabrate communities and sediments as pollution indicators for heavy metals in the River Adige Italy. Water Res., 22, 1353, 1988.

12. RAJENDRAN A., DILEEP KUMAR M., BAKKER J.F. Control of manganese and iron in Skagerrak sediments northeastern North Sea.Chem. Geol., 98, 111, 1992.

13. QU C., MA Z., YANG J., LIE Y., BI J., HUANG L. Human Exposure Pathways of Heavy Metal in a Lead-Zinc Mining Area, in E Asrari (ed.). Heavy Metal Contamination of Water and Soil: Analysis, assessment, and remediation strategies, Apple Academic Press, Oakville, Ontario, 129, 2014, ISBN 9781771880046.

14. OKORIE A., ENTWISTLE J., DEAN J.R. Estimation of daily intake of potentially toxic elements from urban street dust and the role of oral bio accessibility testing. Chemosphere. 86, 460, 2012.

15. FACCHINELLI A., SACCHI E., MALLEN L. Multivariate statistical and GIS-based approach to identify heavy metal sources in soils. Environ. Pollut., 114, 313, 2001.

16. BORUVKA L., VACEK O., JEHLICKA J. Principal component analysis as a tool to indicate the origin of potentially toxic elements in soils. Geoderma., 128, 289, 2005.

17. YALCIN M.G., NARIN I., SOYLAK M. Heavy metal contents of the Karasu Creek sediments, Nigde, Turkey. Environ. Monit. Assess., 128, 351, 2007.

18. YANG J., CHEN L., LIU L.Z., SHI W.L., MENG X.Z. Comprehensive risk assessment of heavy metals in lake sediment from public parks in Shanghai. Ecotoxicol. Environ. Saf., 102, 129, 2014.
19. CHILD D. The essential of factor analysis. Hold Rinehart and Winston Ltd. London, 107, 1970.

20. LAWLEY D.N., MAXWELL A.E. Factor analysis as a statistical method, $2^{\text {nd }}$ edn Butterworth and Co., Ltd. London, 153, 1971.

21. JÖRESKOG K.G., KLOVAN J.E., REYMENT R.A. Geological factor analysis. Elservier. Amsterdam, 178, 1976.

22. ADAM A.M.A., ELTAYEB M.A.H. Multivariate statistical analysis of radioactive variables in two phosphate ores from Sudan. J. Environ. Radioact., 107, 23, 2012.

23. ERSOY S. Analysis of the structural unit and evolution of the Western Taurus (Lycia) Nap. TMMOB. Org. Geol. Engr., 37, 5, 1990 [In Turkish].

24. BRUNN J.H., GRACIANSKY P.Ch.De., GUTNIC M., JUTEAU T., LEFEVRE R., MARCOUX J., MONOD O. POISSON, A. Structures majeureset correlations stratigraphi ques dansles Taurides occidentales. Bull. Soc. Geol. France., 12, 515, 1970.

25. BRADY N.C. The Nature and properties of soils. 8thEdn. Macmillan. New York, 636, 1974.

26. YALCIN M.G., ILHAN S. Multivariate analysis to determine the origin of potentially harmful heavy metals in beach and Dune sediments from Kizkalesi Coast (Mersin), Turkey. Bull. Environ. Contam. Toxicol., 81, 57, 2008.

27. JAIN C.K., GRUPTA H., CHAKRAPANI G.J. Enrichment and fractionation of heavy metals in bed sediments of River Narmada, India. Environ. Monit. Assess., 141, 35, 2008.

28. LE MAITRE R.W. Numerical petrology. Elsevier Scientific Publishing Company. Amsterdam, 108, 1982.

29. KRAUSKOPF K. Introduction to geochemistry. McGrawHill Book Company, 123, 1979.

30. TUREKIAN K.K., WEDEPOHL K.H. Distribution of the elements in some major units of the Earth's Crust. Geol. Soc. Am. Bull., 72, 175, 1961.

31. TKKY. (Soil Pollution Control Regulation). 2005, Official Gazette No. 25831, Ankara, 31 May 2005 [In Turkish].

32. MICÓ C., PERIS M., RECATALA L., SANCHEZ J. Assessing heavy metal sources in agricultural soils of an European Mediterranean area by multivariate analysis, chemosphere, 65 (5), 863, 2006.

33. YALCIN M.G., SETTI M., KARAKAYA F., SACCHI E., ILBEYLI N. Geochemical and mineralogical characteristics of beach sediments along the coast between Alanya and Silifke (Southern Turkey). Clay Minerals, 50, 233, 2015.

34. YALCIN F., NYAMSARI D.G., PAKSU E., YALCIN M.G. Statistical assessment of heavy metals distribution and contamination of beach sands of Antalya- Turkey: an approach to the multivariate analysis techniques. Filomat, 2016, (accepted).

35. COSKUN B. İskenderun Körfezi (Hatay) sahillerinin çevresel şartları ile ilgili ağır metal dağılımının ve dane boylarının incelenmesi. Nigde University, Thesis, 114, 2009 [In Turkish]. 
